\title{
Geology, geochemistry and petrology of basalts from Paraná Continental Magmatic Province in the Araguari, Uberlândia, Uberaba and Sacramento regions, Minas Gerais state, Brazil
}

Geologia, geoquímica e petrologia de basaltos da Província Magmática Continental do Paraná nas regiões de Uberlândia, Araguari, Uberaba e Sacramento, Minas Gerais

\author{
Lucia Castanheira de Moraes ${ }^{1}$, Hildor José Seer ${ }^{1 *}$, Leila Soares Marques²
}

\begin{abstract}
This study covers the region between the cities of Sacramento and Araguari/Uberlandia (Minas Gerais State, Brazil), where basalt flows from the Parana Continental Magmatic Province outcrop. The investigated rocks present tholeiitic signature, with high titanium content, and are classified as Pitanga magma-type. The preserved basalt thickness is between 10 and 200 meters and individual flows do not exceed 15 meters thick. Flows were identified as sheet lobes, smaller and thinner flows units — stacked laterally and vertically forming compound lavas —, or frontal, centimetric lobes. The basalt flows show decimetric to metric intercalations of clastic sedimentary rock, with depositional characteristics that can vary from aeolian to lacustrine, and are important markers on prevailing environmental conditions. The plagioclases are dominantly labradorite and pyroxene is augite, whereas olivine can be hyalosiderite or hortonolitelferrohortonolite. The behavior of the major, minor and trace elements is compatible with the presence of at least two parental magmas, which were subjected to fractional crystallization mainly of plagioclase, clinopyroxene, ilmenite and magnetite. There is a chemistry distinction between basalts from Sacramento to those from Araguari/Uberlandia region, the former one showing more evolved than the last one. The high (La/Lu)N values are indicative of partial melting of a garnet peridotite, while the Rare Earth Elements (REE) values are indicative of fractional crystallization.
\end{abstract}

KEYWORDS: Paraná-Etendeka Province; Lithostratigraphy; Petrography; Lithochemistry; Mineral chemistry.

\section{INTRODUCTION}

Continental flood basalt provinces are huge eruptive events characterized by their phenomenal volumes of tholeiitic basalts erupted in a very short time range and in a continental environment from fissure systems in the Earth's crust (Hooper 2000). One of these, the Paraná-Etendeka Province (PEP), associated with the opening of the South Atlantic Ocean (Renne et al. 1992, Peate et al. 1992, Turner et al. 1994), occupies an estimated area of $1,300,000 \mathrm{~km}^{2}$ distributed across Brazil, Argentina, Uruguay, Paraguay and Namibia (Fig. 1).
The Brazilian portion of the PEP volcanic rocks (Serra Geral Group; Rossetti et al. 2017) was formed in the final phase of the Paraná Basin. This was an intracratonic and polyhistoric basin, which was part of the Gondwana Continent, dominated in its interior, at that time, by the arid climate (Scherer 2002, Jerram \& Stollhofen 2002). These volcanic rocks are mainly of basaltic composition and overlap the aeolian deposits of the Botucatu Formation, and, in some places, they are intercalated. Sills, mainly located in the northern area, as well as the mafic dyke swarms of Ponta Grossa, Serra do Mar and Florianópolis, are associated to

${ }^{1}$ Centro Federal de Educação Tecnológica de Minas Gerais - Araxá (MG), Brazil. E-mails: 2013luciam@gmail.com; hildorster@gmail.com ${ }^{2}$ Instituto de Astronomia, Geofísica e Ciências Atmosféricas, Universidade de São Paulo - São Paulo (SP), Brazil. E-mail: leila.marques@usp.br *Corresponding author

Manuscript ID: 20170091. Received on: 08/07/2017. Approved on: 11/29/2017. 
the volcanism (Ernesto et al. 2002), and together the extrusive and intrusive rocks compose the Paraná Continental Magmatic Province (PCMP). The intrusive rocks are predominantly basic in composition (micro-gabros), and all of them show similar geochemical characteristics to the associated volcanic rocks (Bellieni et al. 1984, Piccirillo et al. 1990, Ernesto et al. 1999).

The PCMP is dominated by tholeiitic basalts and andesibasalts (>90\%), although significant quantities of two compositionally distinct groups of silicic volcanics - Palmas (dacites and rhyolites with low-Ti content) and Chapecó types (dacites with higher-Ti content) — are found along the southern and eastern parts of the province (Mantovani et al. 1985, Bellieni et al. 1986, Piccirillo \& Melfi 1988, Peate 1997). Peate et al. (1992) subdivided mafic magmatism into six types (Fig. 1A): Urubici, Pitanga, Paranapanema (high $\mathrm{TiO}_{2}$ ) and Gramado, Esmeralda and Ribeira (low $\mathrm{TiO}_{2}$ ). The northern PCMP is dominated by Pitanga and Paranapanema basalts, whereas the Gramado and Esmeralda tholeiites occur in southern PCMP. The Ribeira and Urubici flows are scarce and occur in the northern and southern PCMP, respectively. Recent studies have shown that some Urubici flows are present in the border region between Minas Gerais and São Paulo states (Machado 2005), as well as dikes crosscutting rocks of the São Francisco Craton, Minas Gerais (Seer et al. 2011, Marques et al. 2016). The age of the main phase of the volcanic activity is concentrated at 134 to $132 \mathrm{Ma}$, according with data obtained by Renne et al. (1992), Thiede and Vasconcelos (2010), and Janasi et al. (2011).

The regional location of the study area is shown in Figure 1B. It is also possible to see the current limits of the PCMP and the stratigraphic column for the Triângulo Mineiro region, Minas Gerais state, in the northeast of the province. Most of the basalts of the PCMP is covered by fluvio-lacustrine sedimentary Upper Cretaceous rocks belonging to the Bauru Basin. The analyzed samples, as well as some by Rocha-Júnior et al. (2013) used for comparison (KS samples), are located in Figure 1C. Much of the information available today from the northern portion of the PCMP is restricted to lithochemical data, without any knowledge of
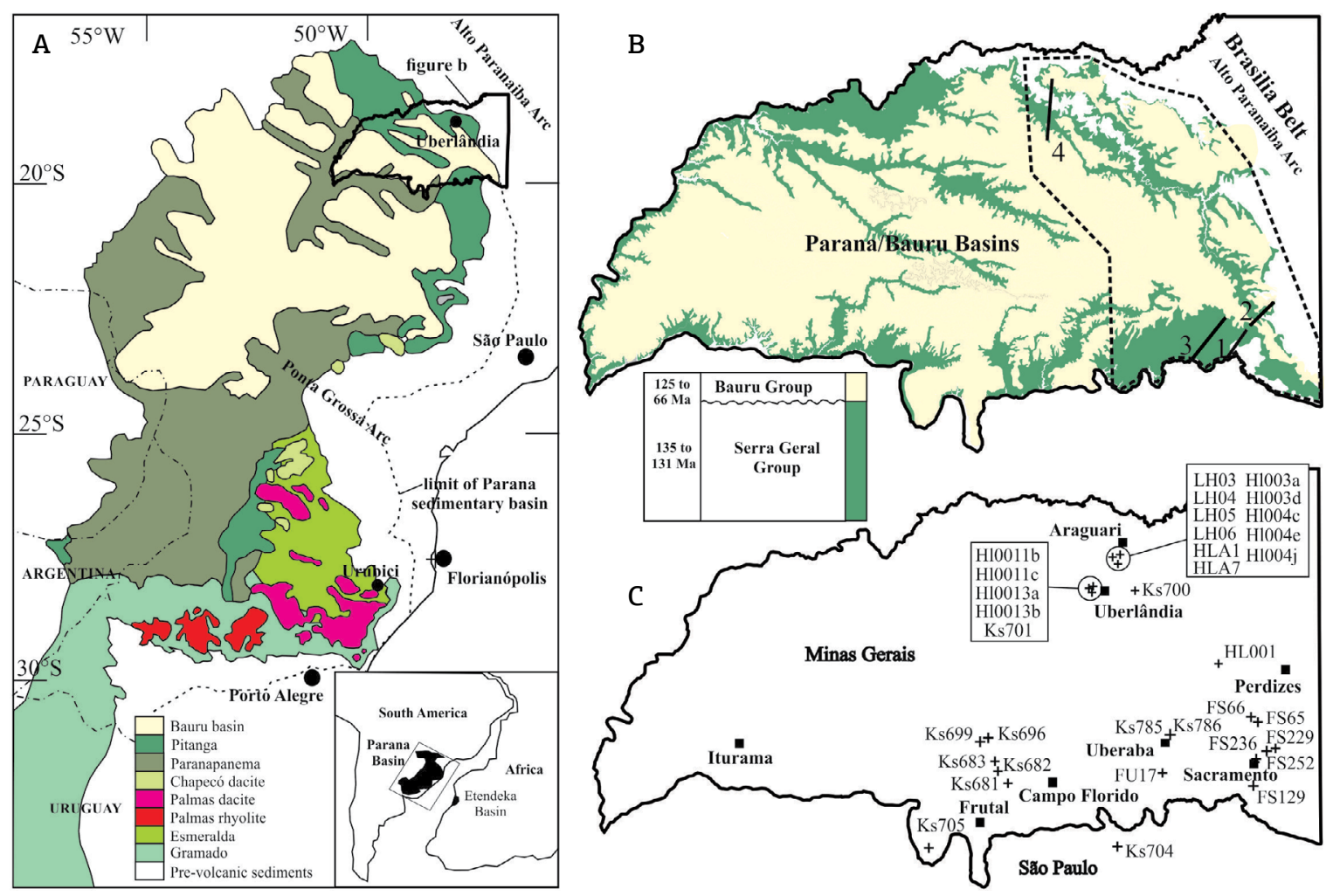

Figure 1. (A) Geological illustration of the Paraná Continental Magmatic Province (PCMP) with its magmatic rocks distribution overlapped by the Bauru Basin. Urubici and Ribeira type magma occurrences are not compatible with this scale. In detail, sketch of the Paraná-Etendeka Province (PEP). Modified from Janasi et al. (2011) and Waichel (2006); (B) geologic map of the Triângulo Mineiro region, modified from Pinto and Silva (2014); 1, 2, 3 and 4 are geologic sections represented in Figure 2. Dashed line limits the studied area; (C) location of analyzed samples and cities of the Triângulo Mineiro region mentioned in the text. 
the lithostratigraphic point of view, with the exception of the works by Araujo (1982), Ferreira (1985), Machado (2005), Pacheco et al. (2017) and Moraes and Seer (2017). The Triângulo Mineiro region is limited by the Alto Paranaíba Arch, a regional topographic high present at least from the Lower Cretaceous and tectonically reactivated during the Upper Cretaceous and Cenozoic. The Alto Paranaíba Arch (Fig. 1A) composes the northeast border of the PCMP and hosts a series of dykes with NW direction and alkaline-carbonatite bodies of Upper Cretaceous age. The NW lineaments, inherited from the Neoproterozoic structure of the region, control the directions of the dykes. According to preliminary petrographic and geochemical data, dykes are potential feeders of the PCMP volcanism in the area. The Alto Paranaíba Arch was the source area of sediments of both, the Botucatu Formation and the Bauru Basin (Hasui 1967, Barcelos 1989, Batezelli 2003), besides an important watershed in the Triângulo Mineiro. It also seems to have behaved as a geographic barrier controlling the climate and the advance of the dunes and lavas of the PCMP.

\section{GEOLOGICAL CONTEXT}

The map of isopacs for the PCMP volcanic rocks in the Triângulo Mineiro region (Batezelli 2003, p. 147) shows a thickness over 1,000 meters in the west (Iturama in Fig. 1C) that decreases eastwards, being less than 100 meters in the Sacramento region. This information can be confirmed in
Figure 2, in which both the paleotopography and the lithology distribution of the Botucatu Formation and PCMP volcanic rocks are represented.

Figure 2 shows an irregular paleotopography, higher in the direction of the Alto Paranaíba Arch, to the northeast. The thickness of sandstones and basalts and the relationships between them are variable. The occupation of the paleorelief begins with the sedimentation in paleovalleys by aeolian sandstones of the Botucatu Formation, whose thicknesses vary from less than two to 110 meters. In the Sacramento region, sections 1 and 2 show dunes over the basement and several aeolian sandstone lenses interspersed in basalt (Figs. 3A and 3B). Between Sacramento and Uberaba, section 3 shows no basal dunes, but many aeolian sandstone lenses. In the Uberlândia/Araguari region (section 4), just two small dunes occur to the north of Araguari city. On the other hand, lenses of alluvial fan and lacustrine deposits are present (Figs. 3C and 3D).

Alluvial fans occur as conglomerate levels dominantly matrix supported and can reach thicknesses of about 1 meter in recurrent channeled shapes. Lacustrine deposits are limited in area and thickness - with minimum length and depth of 50 and 2 meters, respectively - , and cover alluvial fans or interspersed basalt flows. Ostracod fossils were found in three of the four lacustrine deposits. Fossilized conifer woods were described in Botucatu Formation, near Uberlândia city (Pires et al. 2011).

The lavas also fill topographical depressions and free spaces between dunes, and the preserved thickness is between 10 and
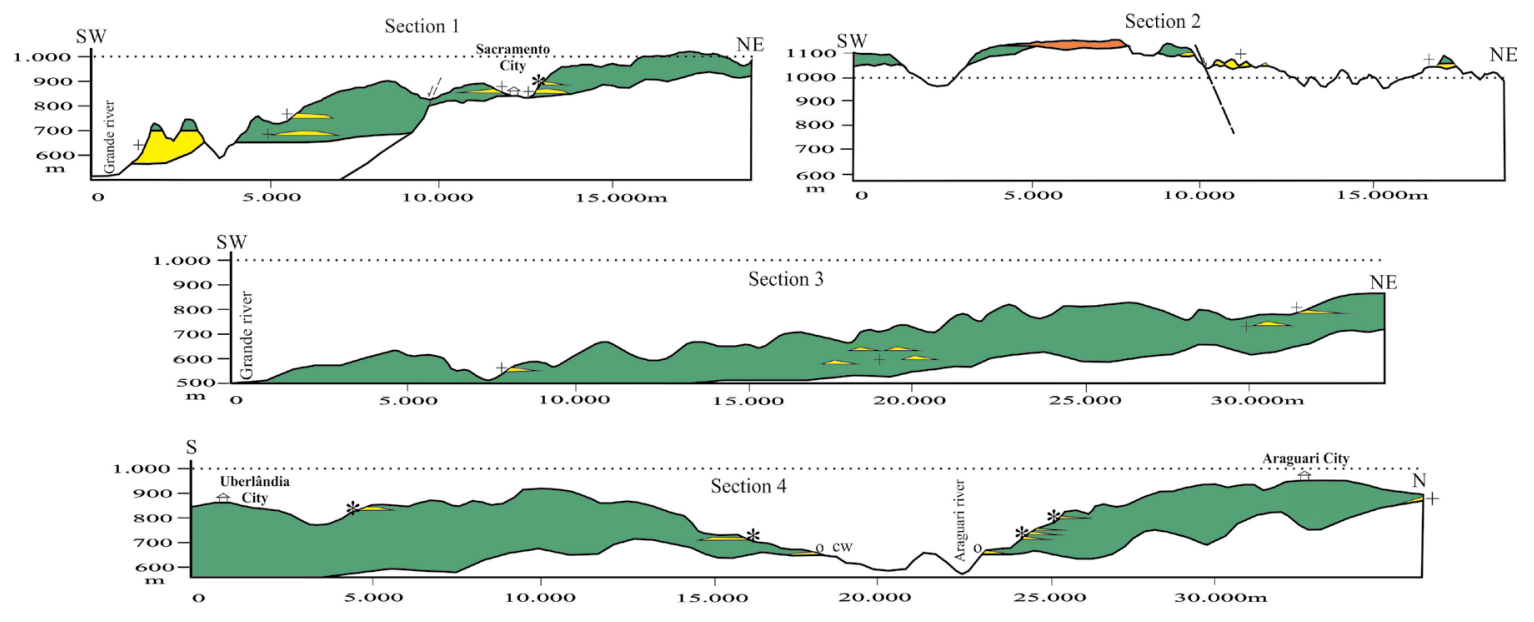

Brasilia Belt Units Botucatu Formation Serra Geral Group Bauru Group Aeolian facies Alluvial facies Lacustrine facies Coniferous woods

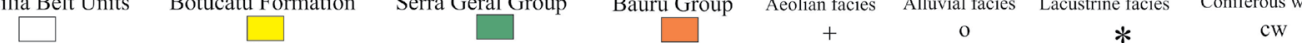

Source: modified from Moraes and Seer, 2017.

Figure 2. Paleorelief of the NE limit of the Paraná Continental Magmatic Province (PCMP) represented in regional geologic cross-sections (location on Figure 1B). The relation between basalts from PCMP and aeolian (+), alluvial (o) and lacustrine $\left({ }^{*}\right)$ dominant sediments of the Botucatu Formation are made explicit. 
200 meters. The contact between sedimentary and basaltic rocks is concordant. Locally it is possible to see interaction between lavas and sand forming peperites/pseudopeperites, degassing pipes in sandstone and grooves produced by basalt flows on still unconsolidated surface (Figs. 4A, 4B, 4C and 4D). The intertrapp sandstone can vary from a few centimeters to a few meters - and may occupy the voids between the upper crust blocks of a pahoehoe flow —, indicating the intermittent nature of the two processes. Nevertheless, these recurring intercalations indicate that aeolian processes and volcanism occurred simultaneously.

Taking into account the quality and extent of the outcrops and the scale studied, it was not possible to determine the actual size of the lava flows. The outcrops visited do not exceed 15 meters thick. Lobes are found in sheet, structured in lava core and fractured crust facies (Fig. 5A), as well as smaller and thinner flows units, $<2$ meters thick, stacked laterally and vertically forming compound lavas (Fig. 5B). Small frontal lobes, centimetric, similar to toes, were also identified in loose blocks or as grooves on the upper crust pahoehoe and on still unconsolidated sandstone surface (Figs. 5C and 5D).

Sheet flows are exposed in basalt quarries. Colonnade usually occurs in the first third from the base of the flow, $<2 \mathrm{~m}$ thick, and eventually is also exposed near the top. Entablature of aphanitic basalt dominates lava flows, being narrower $(<30 \mathrm{~cm}$ wide), irregular and twisted. Fan radiate
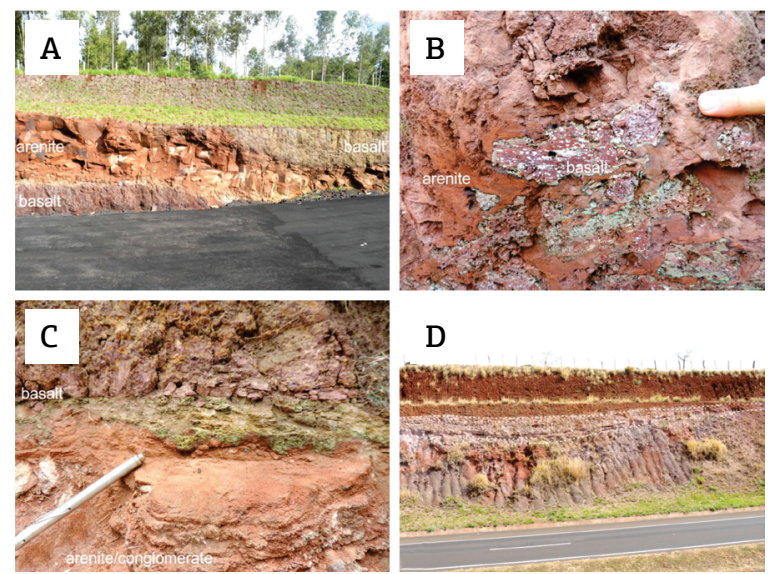

Figure 3. Sedimentary rocks of the Botucatu Formation and their field relations. (A) Aeolian sandstone lenses interspersed with basalt flows; (B) aeolian sandstone occupying voids in the upper crust blocks of basalt flow; (C) alluvial fan matrix supported conglomerate and sandstone from the Botucatu Formation overlaid by lava flow in irregular contact. The light green layer at the base of the lava flow represents rapid quenching of the lava, already altered; (D) lacustrine deposit (white dashed line) interspersed with lava flow. columns can be present (Fig. 5E) and exhibit a nucleus infilled with brecciated and hydrothermally altered material. The brecciated rubble top of the flow has abrupt contacts with the underlying entablature unit via decimetric chillzone. In general, this level is rich in vesicles/amygdales that can be flattened or spherical. They vary between 0.5 and $1 \mathrm{~cm}$ in diameter and are filled by silica, calcite, zeolites, or celadonite, which is predominant. At the entablature rubbly-top transition, gas blisters $(5$ to $25 \mathrm{~cm}$ ) that can be flattened, infilled with chalcedony and quartz, \pm calcite crystals occur. The rubbly surface of the flow hardly exceeds 1 meter in length and consists of clasts of basalt within a fragmental basalt matrix-supported breccia. Alternatively, the clasts may be highly vesicular scoria and the spaces between the fragments may be filled by aeolian sand or cemented by carbonate.

Noteworthy is the presence of two sets of pillow lavas (5.7 and 7.4 meters average thickness, respectively) that interact with fluvio-lacustrine sediments in area situated between the cities of Uberlândia and Araguari, along the Central Atlantic Railway (FCA), in a location known as Fundão (Moraes \& Seer 2017). This interaction gives rise to peperites as interpillow material, which may also be formed by hyaloclastite and fragments of lava, intrinsically mixed to the sediments in a complex way. The basal set of pillows, sized between 30 to over 150 centimeters, with hollow or filled center, is well
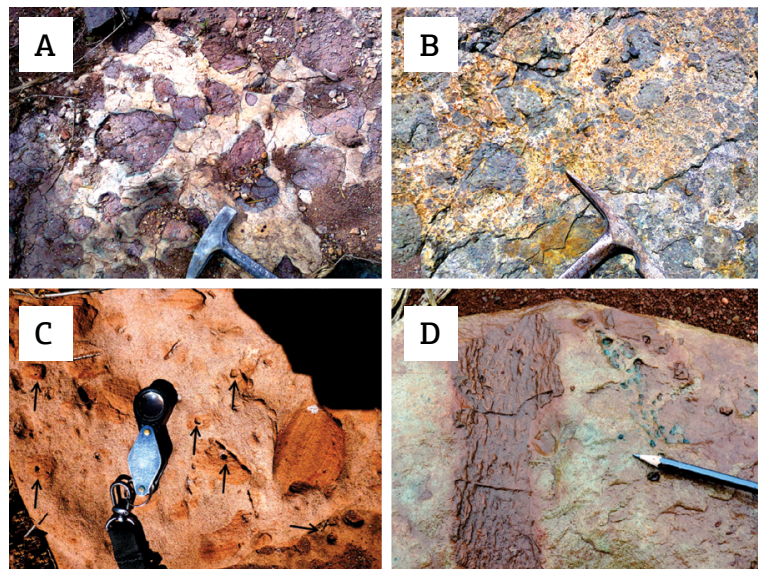

Figure 4. Sediment/lava field relationships: (A) heavily weathered peperite, with rounded fragments of oxidized-aphanitic basalt that has clay-sandy infilled vesicles in the mid of a clay-sandy matrix. Fragment edges show a reaction rim; (B) brecciated rubble surface filled by aeolian sand or cemented by carbonate/ zeolite/chalcedony. The field relationship allow distinguishing both A and B structures; (C) blister of degassing in fractured sandstone due to lava flow action; (D) grooves and basalt remnants due to the passage of small lava lobes in still unconsolidated sandstone surface. 
preserved, and the pillows have chilled rim. The upper set is heavily weathered, and pillows are wrapped in fragments of sandstone, sandy mudrock and mudrock, but show compact arrangement — unlike the basal set, that may show high or very low packaging.

In general, the basalt is fine-grained to aphanitic, with a dark-gray to a greenish-dark gray color, sometimes reddish due to weathering, and consists of microphenocrysts of plagioclase and pyroxene and, less commonly, olivine. The mesostasis is dominated by crystals of plagioclase, pyroxene, magnetite, maghemite and ilmenite. There is a difference between textures of entablature and colonnade basalts; in the former one, volcanic glass is conspicuous, microlites are abundant, opaque crystals are predominantly skeletal, and swallowtail-like textures are common in plagioclase (Fig. 6A). On the other hand, colonnade basalts have phenocrysts with euhedral tendency, sometimes zoned, and coarser mesostasis in predominantly intergranular texture, sub- to euhedral opaque minerals and interstitial and localized glass (Fig. 6B). Where present, microvesicules/microamygdales $(<2 \mathrm{~mm})$ are spherical to irregular, dominantly filled by celadonite, but also by silica, zeolites and calcite (Fig. 6C). The borders of basalt flows tend to be vitreous, with dispersed euhedral crystals of plagioclase and clinopyroxene and amoeboid vesicles (Fig. 6D).

\section{MATERIALS AND METHODS}

The petrographic studies were performed on 28 polished thin sections at the Centro de Pesquisas Professor Manoel Teixeira da Costa of the Geoscience Institute of the Universidade Federal de Minas Gerais (UFMG). The minerals were analyzed by electronic microprobe in the laboratories of the Universidade Federal de Goiás (UFG) (153 analyses) and the Universidade Estadual Paulista "Júlio de Mesquita Filho" (UNESP) (252 analyses), of which 113 in pyroxene, 184 in plagioclase, 88 in oxides, 9 in olivine and 11 in alteration minerals. The polished thin sections were carbon film coated, and analytical work was performed at $15 \mathrm{kV}$ and $20 \mathrm{nA}$. The data were processed using the Gabbrosoft Project worksheets (http://www.gabbrosoft. org), the WinPyrox (Yavuz 2013) and the Igpet software.

Whole-rock chemical analysis of four samples for major, minor, trace and rare earth elements were performed at Geosol laboratories, while 17 at UNESP ones. The percent differences for major and minor elements of sample HL004C (analyzed at GEOSOL and at UNESP) are lower than $4.8 \%$, indicating that the results are compatible, without analytical bias. Samples were crushed, split and pulverized in mechanical agate mortar. At UNESP, they were analyzed by $X$-ray fluorescence $(X R F)$ after $\mathrm{Li}_{2} \mathrm{~B}_{4} \mathrm{O}_{7} / \mathrm{LiBO}_{2}$
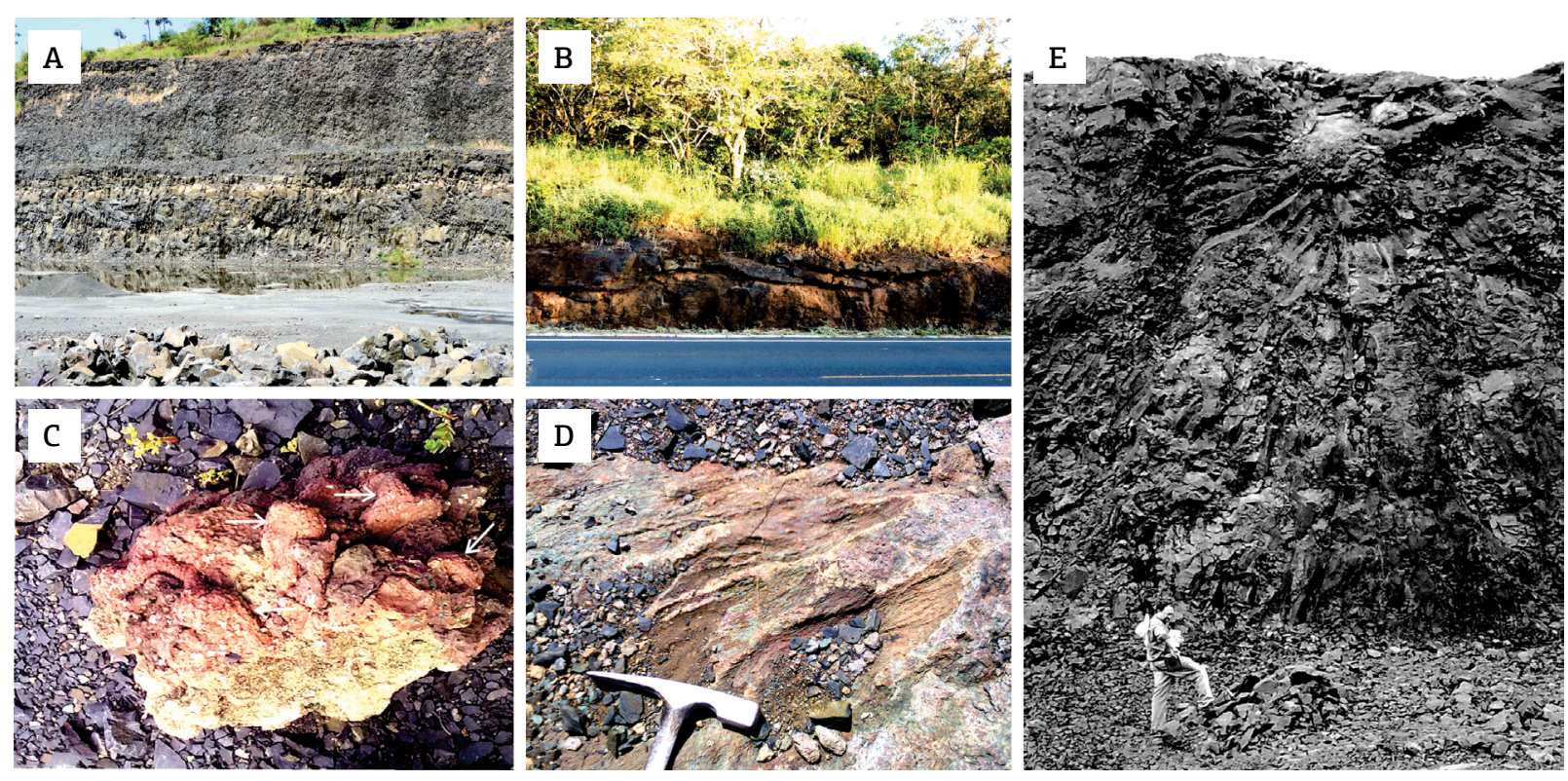

Figure 5. Characteristics of basaltic flows: (A) sheet flows with many lobes. Note short but well developed colonnade at the base flows and entablature, which is dominant and extremely fractured; (B) compound lavas formed by thinner, smaller lava units stacked up; (C) small basalt toes, rusty and vesicular, flowing through the void spaces of a brecciated rubbly surface. Well-formed crystals of analcime can be seen in both; (D) grooves of small lava lobes on the top of brecciated pahoehoe flow. Note the breccia crust was still unconsolidated when the basaltic lobes flowed over it; (E) fan radiated columns from a core infilled with brecciated and hydrothermalized material. 
fusion and LOI determined by gravimetric analysis (Nardy et al. 1997). At GEOSOL, major elements were analyzed by inductively coupled plasma optical emission spectrometry (ICP-OES); minor and trace elements by inductively coupled plasma mass spectrometry (ICP-MS). The relative accuracy for major and minor elements in both laboratories is $1 \%$, whereas for trace elements it is within $\pm 3 \%$. Major oxide contents were recalculated to $100 \%$ on an anhydrous basis. The data were processed and plotted using the softwares Igpet and Petrograph (Petrelli et al. 2005).

\section{MINERAL CHEMISTRY}

Modal mineralogy is on average $51 \%$ plagioclase, $36 \%$ pyroxene, $7 \%$ oxides and $4 \%$ olivine, which, however, may reach $6 \%$ or be absent. This result is consistent with the norms calculated for the chemically analyzed samples, where five samples have normative olivine and 17 do not. In the latter one, normative quartz is present. Normative apatite and ilmenite occurs in all samples.

The Ab-Or-An diagram (Fig. 7) shows the result of the analysis of 100 microphenocrysts and 41 microlites
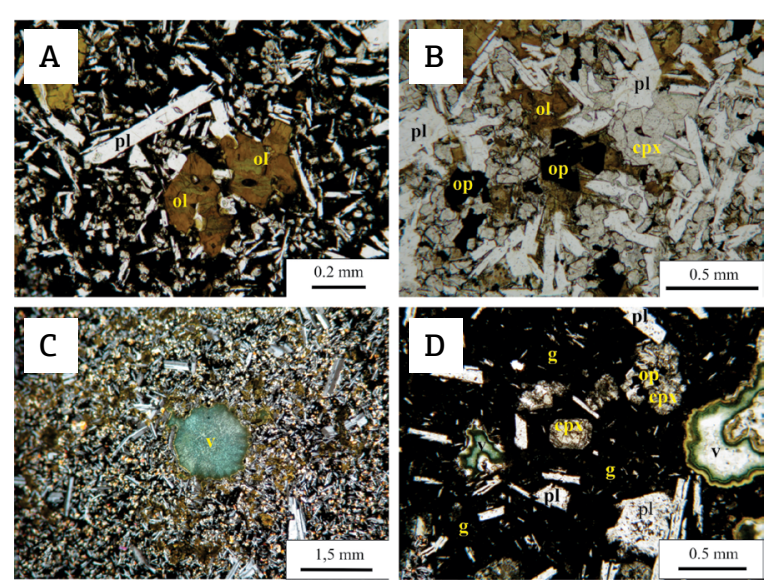

Pl: plagioclase; cpx: clinopyroxene; op: opaque mineral; g: glass; v: vesicle.

Figure 6. Representative features in thin sections. (A) Plagioclase and olivine (altered to iddingsite) phyric basalt with acicular plagioclase crystals and seeds of clinopyroxene in the middle of indistinguishable oxides and glassy matrix. Parallel polarizers; (B) magnetite and augite intergranular to plagioclase crystals and sub-ophitic texture in fine-grained basalt with subordinated glass. Parallel polarizers; (C) finegrained basalt with spherical vesicle filled with celadonite and silica. Crossed polarizers; (D) amoeboid amygdule, filled with celadonite and silica, set in a vitreous mesostasis and sparse pyroxene and plagioclase crystals, $\leq 0.5 \mathrm{~mm}$, which may be zoned. Parallel polarizers. of plagioclase (Tab. 1). Some plagioclases are characterized by compositional zoning (Figs. $8 \mathrm{~A}$ and $8 \mathrm{~B}$ ) and, when it occurs, their core and edge were analyzed separately. Among the micro-phenocrysts analyzed, sample HL002 has the most calcic crystal $\left(\mathrm{An}_{75} \mathrm{Ab}_{24} \mathrm{Or}_{1}\right)$, while the HL003b $\left(\mathrm{An}_{51} \mathrm{Ab}_{46} \mathrm{Or}_{3}\right)$, the least one. In mesostasis, the variations are between $\mathrm{An}_{63} \mathrm{Ab}_{35} \mathrm{Or}_{2}$ (HL002) and $\mathrm{An}_{47} \mathrm{Ab}_{49} \mathrm{Or}_{4}$ (HL003b), in a coherent and expected way. Although normal zonation is present (for example in HL004c sample), reverse zoning occurs too, and in some of the analyzed samples the nuclei of micro-phenocrysts are less calcic than those ones of the mesostasis. Fig. 9 shows edge-to-edge profiles for two zoned micro-phenocrysts. Profile A (FU463) shows composition $\mathrm{An}_{68}$ at the edges and $\mathrm{An}_{47}$ at the core. Profile B (FU687b) shows rims with composition around $\mathrm{An}_{48}$, depletion in calcium to $\mathrm{An}_{46.5}$ followed by enrichment, reaching the core with $\mathrm{An}_{50}$. Although the variation is small, it draws attention to a complex magmatic trajectory.

The composition of 37 micro-phenocrysts and 30 microlites of pyroxenes is shown in Fig. 10A, the Wo-En-Fs ternary diagram (Morimoto 1988), and Table 2 shows some representative analyses and formulae of them. With the exception of two crystals from LH04 sample that fall in the pigeonite field, all the other pyroxenes analyzed are augites. Fig. 10B shows the compositional variation profiles obtained in zoned micro-phenocrysts. A normal variation, with enrichment in Fs towards the rim, is prevailing, except for the micro-phenocrysts present in samples HL004B1, HL004B2, LH04-2 and LH04-3. In these ones, some micro-phenocrysts are

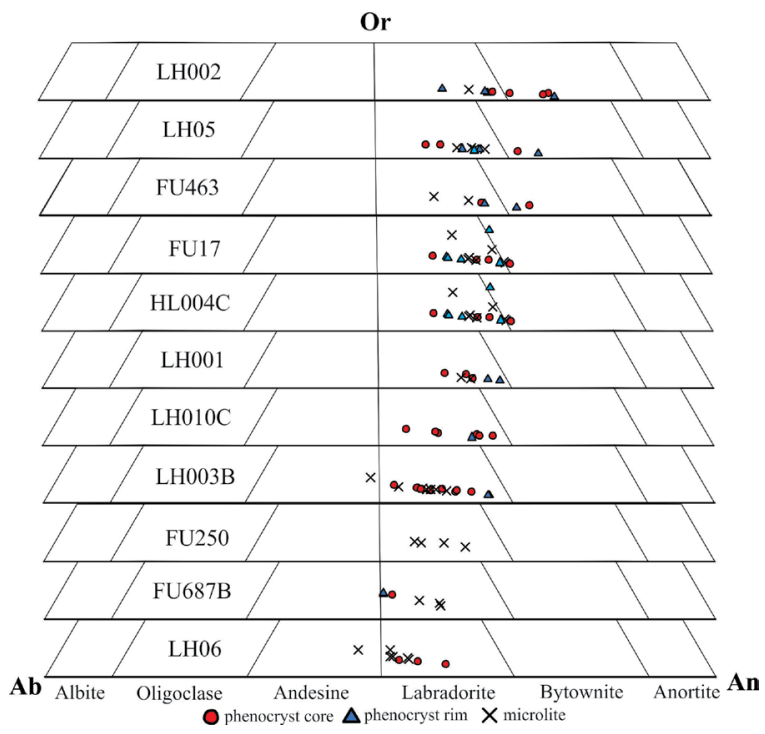

Figure 7. Compositional variation of plagioclase of the basalt flows (Pitanga magma type) studied according Or-Ab-An diagram of Deer et al. (2003). 
Table 1. Representative analysis and formulae of plagioclase.

\begin{tabular}{|c|c|c|c|c|c|c|c|c|c|c|c|c|}
\hline Sample & $\begin{array}{l}\text { FU17 } \\
\text { P C }\end{array}$ & $\begin{array}{c}\text { FU17 } \\
\text { P R }\end{array}$ & $\begin{array}{l}\text { FU17 } \\
\text { MP C }\end{array}$ & $\begin{array}{l}\text { HLO01 } \\
\text { P C }\end{array}$ & $\begin{array}{c}\text { HL001 } \\
\text { P R }\end{array}$ & $\begin{array}{l}\text { HL001 } \\
\text { MP C }\end{array}$ & \begin{tabular}{|c|} 
HL004c \\
P C
\end{tabular} & \begin{tabular}{|c|} 
HL004c \\
P R
\end{tabular} & $\begin{array}{c}\text { HL004c } \\
\text { MP C }\end{array}$ & $\begin{array}{l}\text { LH05 } \\
\text { P C }\end{array}$ & $\begin{array}{l}\text { LH05 } \\
\text { P R }\end{array}$ & $\begin{array}{l}\text { LH05 } \\
\text { M PC }\end{array}$ \\
\hline \multicolumn{13}{|c|}{ Component } \\
\hline $\mathrm{SiO}_{2}$ & 50.580 & 53.330 & 52.330 & 52.400 & 51.150 & 52.320 & 50.420 & 52.970 & 54.220 & 53.430 & 51.860 & 51.530 \\
\hline $\mathrm{TiO}_{2}$ & 0.110 & 0.170 & 0.130 & 0.000 & 0.000 & 0.000 & 0.000 & 0.000 & 0.000 & 0.000 & 0.000 & 0.000 \\
\hline $\mathrm{Al}_{2} \mathrm{O}_{3}$ & 30.080 & 27.840 & 28.880 & 30.220 & 30.650 & 29.950 & 31.320 & 29.310 & 28.430 & 29.140 & 30.340 & 30.440 \\
\hline $\mathrm{FeO}_{\mathrm{t}}$ & 0.850 & 0.920 & 0.930 & 0.730 & 0.870 & 0.790 & 0.800 & 0.750 & 0.970 & 0.750 & 0.730 & 0.860 \\
\hline $\mathrm{CaO}$ & 13.380 & 11.390 & 11.920 & 12.830 & 13.600 & 12.730 & 14.370 & 12.060 & 11.240 & 11.860 & 13.140 & 12.910 \\
\hline $\mathrm{Na}_{2} \mathrm{O}$ & 3.140 & 4.070 & 3.690 & 3.910 & 3.480 & 3.950 & 3.090 & 4.200 & 4.790 & 4.360 & 3.760 & 3.840 \\
\hline $\mathrm{K}_{2} \mathrm{O}$ & 0.280 & 0.500 & 0.430 & 0.290 & 0.240 & 0.280 & 0.240 & 0.380 & 0.460 & 0.370 & 0.280 & 0.290 \\
\hline Total & 98.420 & 98.220 & 98.310 & 100.380 & 99.990 & 100.020 & 100.240 & 99.670 & 100.110 & 99.910 & 100.110 & 99.870 \\
\hline \multicolumn{13}{|c|}{ Cations based on 32 oxygen } \\
\hline $\mathrm{Si}$ & 9.369 & 9.843 & 9.663 & 9.470 & 9.337 & 9.519 & 9.198 & 9.653 & 9.831 & 9.705 & 9.436 & 9.405 \\
\hline $\mathrm{Ti}$ & 0.015 & 0.024 & 0.018 & 0.000 & 0.000 & 0.000 & 0.000 & 0.000 & 0.000 & 0.000 & 0.000 & 0.000 \\
\hline $\mathrm{Al}$ & 6.565 & 6.057 & 6.285 & 6.482 & 6.593 & 6.420 & 6.733 & 6.294 & 6.075 & 6.238 & 6.506 & 6.548 \\
\hline $\mathrm{Fe}(\mathrm{ii})$ & 0.132 & 0.143 & 0.143 & 0.111 & 0.133 & 0.121 & 0.122 & 0.114 & 0.147 & 0.114 & 0.111 & 0.131 \\
\hline $\mathrm{Ca}$ & 2.655 & 2.252 & 2.358 & 2.501 & 2.660 & 2.481 & 2.808 & 2.354 & 2.183 & 2.308 & 2.561 & 2.524 \\
\hline $\mathrm{Na}$ & 1.127 & 1.456 & 1.321 & 1.380 & 1.232 & 1.395 & 1.093 & 1.483 & 1.683 & 1.536 & 1.326 & 1.360 \\
\hline $\mathrm{K}$ & 0.066 & 0.118 & 0.101 & 0.066 & 0.056 & 0.066 & 0.057 & 0.085 & 0.107 & 0.087 & 0.066 & 0.067 \\
\hline Cat sum & 19.929 & 19.892 & 19.888 & 20.011 & 20.011 & 20.001 & 20.011 & 19.984 & 20.026 & 19.990 & 20.007 & 20.034 \\
\hline \multicolumn{13}{|c|}{ End-member (\%) } \\
\hline An & 69.000 & 58.870 & 62.390 & 63.370 & 67.370 & 62.950 & 70.950 & 60.010 & 54.950 & 58.710 & 64.780 & 63.880 \\
\hline $\mathrm{Ab}$ & 29.290 & 38.050 & 34.940 & 34.950 & 31.210 & 35.380 & 27.620 & 37.820 & 42.370 & 39.090 & 33.550 & 34.430 \\
\hline Or & 1.710 & 3.080 & 2.680 & 1.680 & 1.420 & 1.670 & 1.430 & 2.170 & 2.680 & 2.200 & 1.670 & 1.690 \\
\hline
\end{tabular}

P: phenocryst; MP: micro-phenocryst; C: core; R: rim.

fairly homogeneous or show significant inverted zoning. In general, there is a negligible variation of the chemical composition from the core $\left(\mathrm{Wo}_{35-41} \mathrm{En}_{39-47} \mathrm{Fs}_{15-24}\right)$ to the rim $\left(\mathrm{Wo}_{36-39} \mathrm{En}_{38-47} \mathrm{Fe}_{14-23}\right)$ of the zoned micro-phenocrysts, and a trend of differentiation is not identified.

Some subhedral micro-phenocrysts of clinopyroxenes in subophitic texture are shown in Fig. 8C, while in the back-scattered image of Fig. 8D a zoned augite micro-phenocryst with about $0.4 \mathrm{~mm}$ in length with subtle zoning can be seen. It partially involves plagioclase crystals, in subophitic texture, and is immersed in mesostasis rich in plagioclase, pyroxene, ilmenite and magnetite microlites, besides glass in the process of devitrification.

Oxides occur as subhedral to euhedral crystals, tabular or skeletal (Figs. 11A and 11B). The ternary FeO vs. $\mathrm{TiO}_{2}$ vs. $\mathrm{Fe}_{2} \mathrm{O}_{3}$ diagram (Akimoto \& Katsura 1959) shows the major solid solution series magnetite-ulvöspinel, hematite-ilmenite and ferropseudobrookite-pseudobrookite. The data of the analyzed oxides (Tab. 3 and Fig. 12) plot on the field of ilmenite. The subordinate presence of titanomaghemite (Katsura \& Kushiro 1961) suggests weathering or low-T oxidation of titanomagnetite or magnetite. The presence of magnetite was attested by magnet in hand samples.

When present, olivine shows alteration to iddingsite, so that preserved crystals are very rare (Figs. 11C and 11D). Nine olivine crystals of three basaltic samples were analyzed

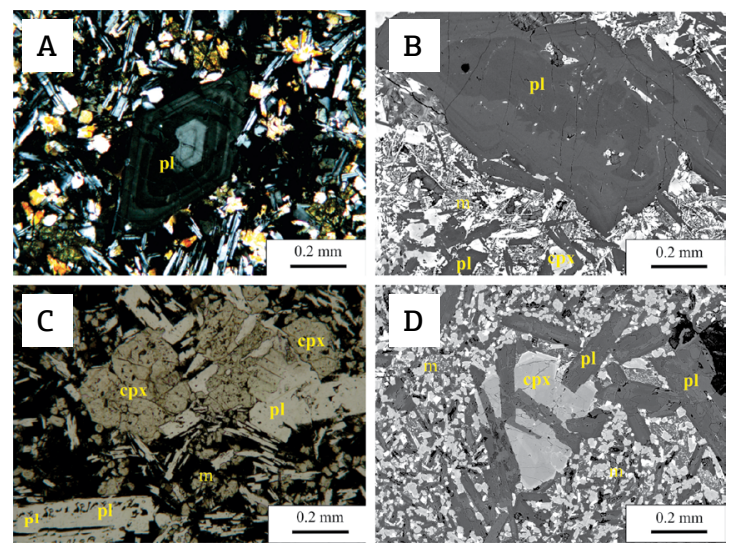

$\mathrm{Pl}$ : plagioclase; cpx: clinopyroxene; m: mesostasis.

Figure 8. Microscopic aspects representative of basalt flows. (A) Micro-phenocryst of concentrically zoned labradorite in a mesostasis rich in plagioclase laths and granules of clinopyroxene, magnetite and olivine already transformed into iddingsite. Part of the black material is volcanic glass. Crossed polarizers; (B) backscattered image showing phenocryst of plagioclase with irregular zoning and inclusions of glass and oxides in sample HLOO1; (C) augites in micro-phenocrysts, showing inclusions of plagioclase, oxides and glass, and immersed in a mesostasis of clinopyroxene, plagioclase, oxides and glass. Parallel polarizers; (D) back-scattered image of augite in micro-phenocryst with distinct marginal zoning and delicate "patchy zoning" within the crystal. 
(Tab. 4, Fig. 13). None of them has significant zonation. FU017 sample shows olivine with a more magnesian composition ( $\mathrm{Fo}_{59} \mathrm{Fa}_{41}$-hyalosiderite), while in samples FU250 and $\mathrm{LH} 05$ olivine is markedly ferriferous (between $\mathrm{Fo}_{35} \mathrm{Fa}_{65}$ and $\mathrm{Fo}_{28} \mathrm{Fa}_{70}$ - hortonolite/ferrohortonolite) according to Deer et al. (2003). Despite this difference in composition, no significant textural distinctions were observed. However, the olivines of sample FU017 are subhedral and slightly rounded, suggesting corrosion, while other ones have more inclusions and almost absence of faces. As for the size, all are about $75 \mu \mathrm{m}$ in the longest length. The few data available do not allow further consideration.

The presence of glass in the basalts mesostasis is very common, as interstitial and localized form or as significant proportions. In either case, devitrification processes are common, and the presence of crystallites is conspicuous (Figs. 14A and 14B).

\section{ROCK CHEMISTRY}

The 22 analyzed samples were divided according to their areal distribution (Tab. 5), being six of them from the Sacramento region, to the southeast, one from the Uberaba area, one from the Perdizes region and 14 from the area between Uberlândia and Araguari cities, to the northwest (see Fig. 1 for location). Table 5 also shows the CIPW Norm for these rocks.

The flows are classified as basalts, in the total alkali-versus-silica (TAS) diagram (Le Bas et al. 1986). The $\mathrm{SiO}_{2}$ concentrations range from 48.10 to $51.81 \mathrm{wt} \%$ and total alkalis between 3.43 and $4.49 \mathrm{wt} \%$ (Fig. 15), and all samples plot in the field of subalkaline volcanic series (Irvine $\&$ Baragar 1971). The rocks have a tholeiitic character, with strong enrichment of iron in relation to alkalis and magnesium $\left(\mathrm{Fe}_{2} \mathrm{O}_{3} \mathrm{t} / \mathrm{MgO}\right.$ between 2.6 and 4.0) and high- $\mathrm{TiO}_{2}$ contents, belonging to the HTi Basalt Group of the PCMP (Bellieni et al. 1984, Peate et al. 1992).

The main characteristic shown by the variation diagrams of major, minor and trace elements against $\mathrm{MgO}$ (Figs. 16 and 17), considered as a magmatic differentiation index, is the separation of two specific fields: one for the more evolved rocks from the Sacramento region, in the southeast of the surveyed area; and the other one for those less evolved rocks from the Uberlândia/Araguari region, at the northwest. The only representative sample of the Uberaba region falls in the intermediate area, between the two groups. Samples from the pillow lavas related basaltic flows behave independently by plotting in between the groups mentioned; four of them overlap the basalts of the Uberlândia/Araguari region, while the other one has lower $\mathrm{MgO}, \mathrm{SiO}_{2}, \mathrm{Al}_{2} \mathrm{O}_{3}, \mathrm{CaO}$ and $\mathrm{Na}_{2} \mathrm{O}$ and overlaps the Sacramento Group. Analyzed together, a negative correlation trend is observed for $\mathrm{SiO}_{2}, \mathrm{Na}_{2} \mathrm{O}, \mathrm{K}_{2} \mathrm{O}$, $\mathrm{P}_{2} \mathrm{O}_{5}$ and (subtle) for $\mathrm{TiO}_{2}$ and positive for $\mathrm{CaO}$ and $\mathrm{Al}_{2} \mathrm{O}_{3}$. There is a strong correspondence with Rocha-Júnior et al. (2013) data, even though those present lower values for $\mathrm{Na}_{2} \mathrm{O}$ and higher for $\mathrm{Al}_{2} \mathrm{O}_{3}$.

According to the parameters proposed by Peate et al. (1992), the studied basalts belong to the Pitanga magma
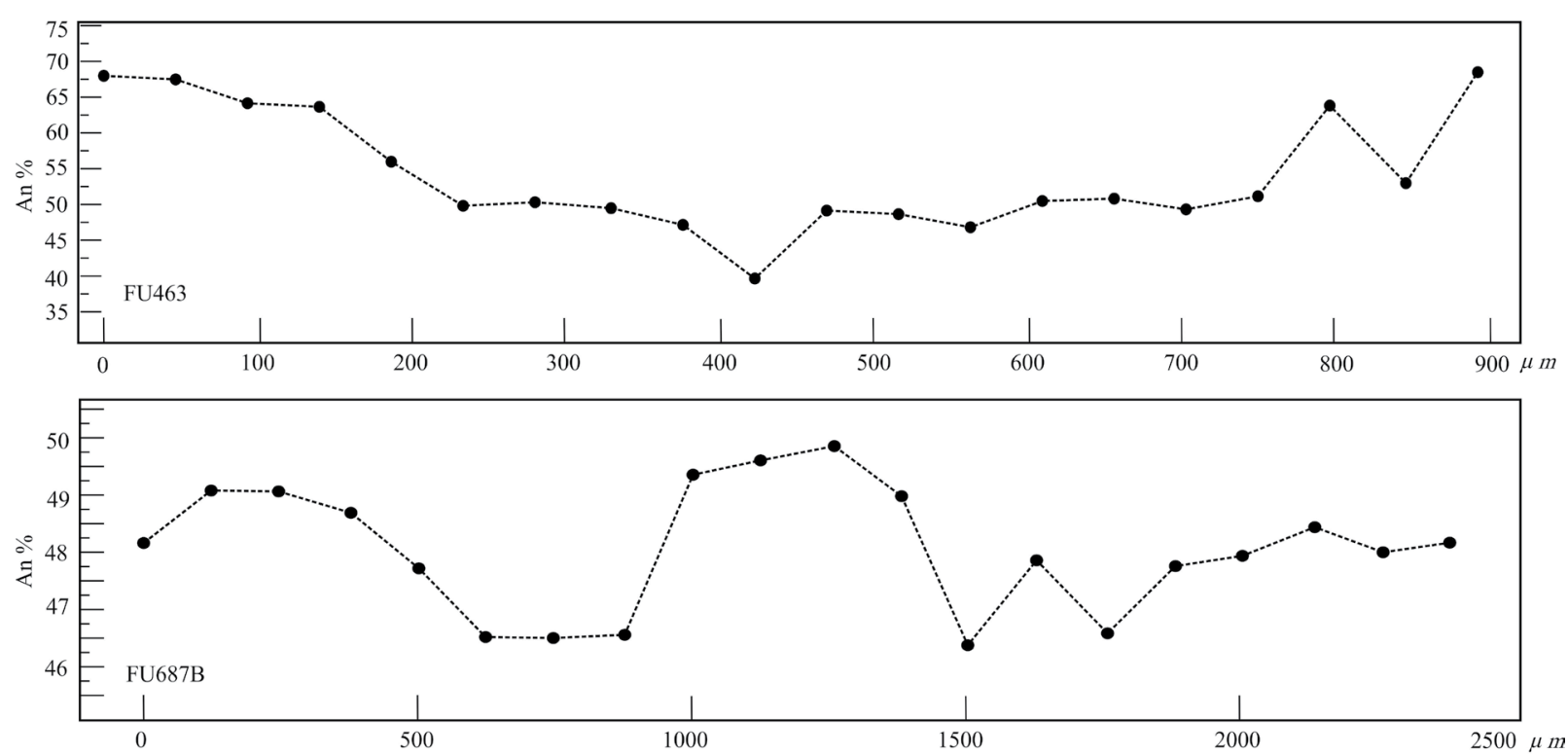

Figure 9. Rim to rim profile in two plagioclase phenocrysts that show very distinct crystallization history. Sample FU 463 shows gradual Ca-enrichment from the center to the edge of the crystal, while the FU687b sample has a more complex history, with a Ca-enriched center and border and a depleted intermediate portion. 

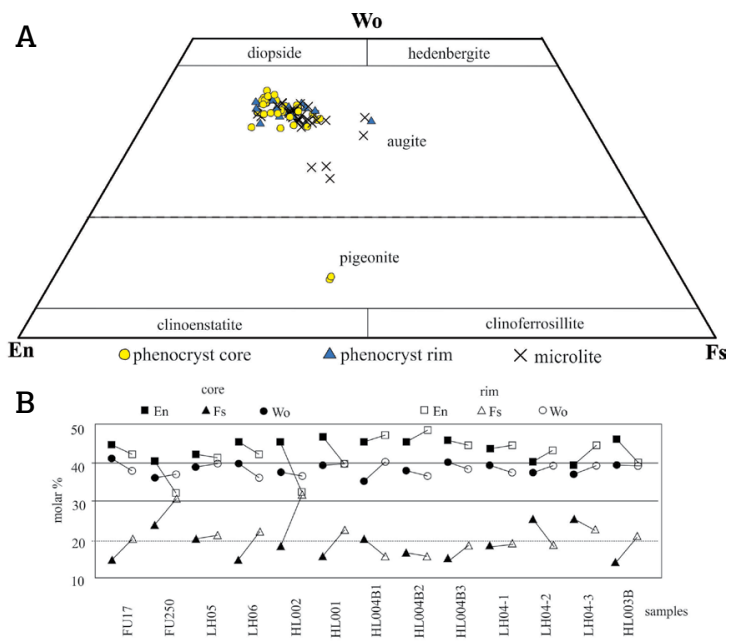

Figure 10. Pyroxene analysis. (A) Compositional variation of pyroxenes according to the ternary diagram (Wo-EnFs) of Morimoto (1988); (C) compositional variation of pyroxenes according to core-rim profile; cpx crystals HL004B 1, HL004B 2, LH04-2 and LH04-3 show inverted zoning, unlike the others, including the two other crystals analyzed for these same samples (HLOO4B 3 and LHO4-1). type. They show $\mathrm{Fe}_{2} \mathrm{O}_{3}$ between 14.27 and $18.48 \mathrm{wt} \%$ with average of $15.04 \mathrm{wt} \%$ and $\mathrm{Sr}$ variation between 375 and $504 \mathrm{ppm}$ with average $412 \mathrm{ppm}$. The $\mathrm{TiO}_{2}$ content varies between 3.21 to $3.97 \mathrm{wt} \%$ with average $3.7 \mathrm{wt} \%$, similar to Urubici magma-type, but in the $\mathrm{Sr} v$ s. $\mathrm{TiO}_{2}$ diagram the samples plot on the Pitanga field (Tab. 6, Fig. 18).

The two groups of samples identified by major elements are also distinguished by the trace elements (Fig. 17). Negative correlation is observed for incompatible elements $\mathrm{Nb}, \mathrm{Ba}, \mathrm{Ce}, \mathrm{Rb}$ and (subtle) $\mathrm{Y}$ and $\mathrm{Zr}$. Ni shows defined positive correlation, whereas for $\mathrm{Sr}$ there is no clear correlation. Figure 19 reinforces the presence of two groups of basalts and the evidence of two parental magmas in this region. With regard to data from RochaJúnior et al. (2013), the correspondence observed for the major and minor elements is observed for the trace elements, although it is not so clear for some samples. In addition, all those samples are more Y-enriched than these under analysis.

Only five samples — from the Uberaba and Uberlândia/ Araguari regions - were analyzed for Rare Earth Elements

Table 2. Some analysis and formulae of representative pyroxenes.

\begin{tabular}{|c|c|c|c|c|c|c|c|c|c|c|c|c|}
\hline Sample & $\begin{array}{l}\text { FU17 } \\
\text { P C }\end{array}$ & $\begin{array}{c}\text { FU17 } \\
\text { P R }\end{array}$ & $\begin{array}{l}\text { FU17 } \\
\text { MP C }\end{array}$ & $\begin{array}{l}\text { HLO01 } \\
\text { P C }\end{array}$ & $\begin{array}{c}\text { HL001 } \\
\text { P R }\end{array}$ & $\begin{array}{l}\text { HL004c } \\
\text { P C }\end{array}$ & \begin{tabular}{|c|} 
HL004c \\
P C
\end{tabular} & $\begin{array}{l}\text { HL004c } \\
\text { MP C }\end{array}$ & $\begin{array}{c}\text { HL004c } \\
\text { MP C }\end{array}$ & $\begin{array}{c}\text { LHO4 } \\
\text { P C }\end{array}$ & $\begin{array}{c}\text { LHO4 } \\
\text { P R }\end{array}$ & $\begin{array}{l}\text { LHO4 } \\
\text { MP C }\end{array}$ \\
\hline \multicolumn{13}{|c|}{ Component } \\
\hline $\mathrm{SiO}_{2}$ & 49.430 & 49.820 & 47.140 & 50.120 & 46.990 & 49.690 & 50.540 & 49.520 & 50.280 & 49.520 & 50.130 & 50.110 \\
\hline $\mathrm{TiO}_{2}$ & 1.260 & 1.150 & 2.150 & 1.160 & 2.640 & 1.460 & 1.070 & 1.440 & 1.110 & 1.180 & 0.960 & 1.140 \\
\hline $\mathrm{Al}_{2} \mathrm{O}_{3}$ & 2.870 & 2.090 & 4.000 & 2.790 & 3.980 & 3.280 & 2.810 & 3.100 & 1.880 & 3.410 & 2.810 & 2.110 \\
\hline $\mathrm{Cr}_{2} \mathrm{O}_{3}$ & 0.260 & 0.030 & 0.080 & 0.000 & 0.000 & 0.000 & 0.000 & 0.000 & 0.000 & 0.000 & 0.000 & 0.000 \\
\hline $\mathrm{FeOt}$ & 9.480 & 12.410 & 12.260 & 9.710 & 14.010 & 10.550 & 10.230 & 12.280 & 13.450 & 11.440 & 11.630 & 12.430 \\
\hline $\mathrm{MnO}$ & 0.230 & 0.230 & 0.250 & 0.230 & 0.300 & 0.260 & 0.240 & 0.270 & 0.370 & 0.270 & 0.310 & 0.300 \\
\hline $\mathrm{MgO}$ & 15.190 & 14.480 & 13.500 & 15.870 & 12.960 & 15.000 & 16.150 & 14.470 & 14.70 & 14.570 & 14.870 & 14.460 \\
\hline $\mathrm{CaO}$ & 19.270 & 17.660 & 18.230 & 18.860 & 17.890 & 19.030 & 18.110 & 17.600 & 17.600 & 18.340 & 18.030 & 18.070 \\
\hline $\mathrm{Na}_{2} \mathrm{O}$ & 0.270 & 0.200 & 0.300 & 0.260 & 0.300 & 0.240 & 0.240 & 0.230 & 0.200 & 0.360 & 0.260 & 0.230 \\
\hline $\mathrm{K}_{2} \mathrm{O}$ & 0.010 & 0.030 & 0.000 & 0.000 & 0.000 & 0.000 & 0.000 & 0.000 & 0.000 & 0.000 & 0.000 & 0.000 \\
\hline Total & 98.260 & 98.100 & 97.900 & 99.000 & 99.070 & 99.510 & 99.390 & 98.910 & 99.590 & 99.090 & 99.000 & 98.850 \\
\hline \multicolumn{13}{|c|}{ Cations based on 6 oxygen } \\
\hline $\mathrm{Si}$ & 1.880 & 0.033 & 1.824 & 1.887 & 1.810 & 1.870 & 1.894 & 1.882 & 1.908 & 1.876 & 1.899 & 1.910 \\
\hline $\mathrm{Ti}$ & 0.036 & 0.094 & 0.063 & 0.033 & 0.077 & 0.041 & 0.030 & 0.041 & 0.032 & 0.034 & 0.027 & 0.033 \\
\hline $\mathrm{Al}$ & 0.129 & 0.001 & 0.182 & 0.124 & 0.181 & 0.146 & 0.124 & 0.139 & 0.084 & 0.152 & 0.126 & 0.095 \\
\hline $\mathrm{Cr}$ & 0.008 & 0.398 & 0.002 & 0.000 & 0.000 & 0.000 & 0.000 & 0.000 & 0.000 & 0.000 & 0.000 & 0.000 \\
\hline $\mathrm{Fe}(\mathrm{ii})$ & 0.301 & 0.007 & 0.397 & 0.306 & 0.451 & 0.332 & 0.320 & 0.390 & 0.427 & 0.362 & 0.368 & 0.396 \\
\hline $\mathrm{Mn}$ & 0.007 & 0.828 & 0.008 & 0.007 & 0.010 & 0.008 & 0.008 & 0.009 & 0.012 & 0.009 & 0.010 & 0.010 \\
\hline $\mathrm{Mg}$ & 0.861 & 0.726 & 0.778 & 0.891 & 0.745 & 0.842 & 0.902 & 0.820 & 0.832 & 0.823 & 0.840 & 0.821 \\
\hline $\mathrm{Ca}$ & 0.785 & 0.015 & 0.756 & 0.761 & 0.739 & 0.768 & 0.727 & 0.717 & 0.716 & 0.744 & 0.732 & 0.738 \\
\hline $\mathrm{Na}$ & 0.020 & 0.001 & 0.022 & 0.019 & 0.022 & 0.018 & 0.018 & 0.017 & 0.015 & 0.026 & 0.019 & 0.017 \\
\hline $\mathrm{K}$ & 0.001 & 0.033 & 0.000 & 0.000 & 0.000 & 0.000 & 0.000 & 0.000 & 0.000 & 0.000 & 0.000 & 0.000 \\
\hline Cat sum & 4.027 & 4.016 & 4.032 & 4.028 & 4.033 & 4.024 & 4.023 & 4.016 & 4.025 & 4.027 & 4.020 & 4.019 \\
\hline \multicolumn{13}{|c|}{ End-member (\%) } \\
\hline Wo & 39.800 & 36.790 & 38.590 & 38.380 & 37.640 & 39.060 & 36.850 & 36.730 & 35.820 & 37.940 & 37.200 & 37.260 \\
\hline En & 43.650 & 41.980 & 39.760 & 44.960 & 37.950 & 42.830 & 45.730 & 42.010 & 41.620 & 41.930 & 42.700 & 41.490 \\
\hline Fs & 15.550 & 20.480 & 20.520 & 15.700 & 23.310 & 17.210 & 16.530 & 20.370 & 21.810 & 18.790 & 19.140 & 20.400 \\
\hline
\end{tabular}

P: phenocryst; MP: micro-phenocryst; C: core; R: rim. 


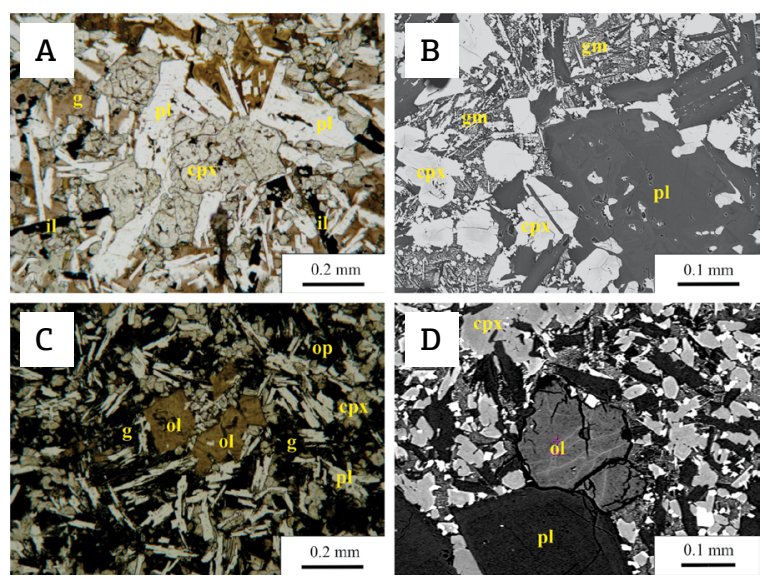

Pl: plagioclase; cpx: clinopyroxene; op: opaque mineral; il: ilmenite; gm: glassy mesostasis; ol: olivine; g: glass.

Figure 11. (A) Crystals of ilmenitebetween clinopyroxene and plagioclase showing intergranular, intersertal and subophitic textures. Some small plagioclase laths show swallowtail termination. Parallel polarizers; (B) back-scattered image showing some subhedral crystals of ilmenite and abundant skeletal microlites in the mesostasis in process of devitrification; (C) small euhedral crystals of olivine, replaced by iddingsite, together with laths of plagioclase, granular clinopyroxene and oxides. Parallel polarizers; (D) backscattered image showing some micro-phenocrysts of well-preserved olivine, plagioclase and clinopyroxene, in a mesostasis rich in clinopyroxene and plagioclase apart from oxides and glass.
(REE). The REE were normalized to the chondrites (Sun \& McDonough 1989) (Fig. 20) and resemble the data of Rocha-Júnior et al. (2013). Heavy REE's are strongly depleted compared to light REE's in the Pitanga magma type. $(\mathrm{La} / \mathrm{Lu})_{\mathrm{N}}$ varies between 8.04 to 9.93 , while the data from Pitanga magma by Rocha-Júnior et al. (2013) are in

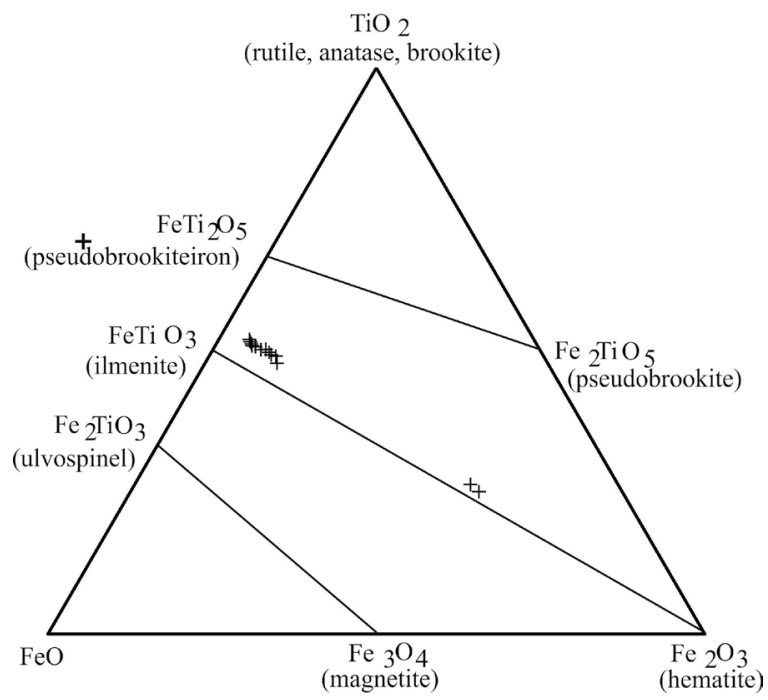

Figure 12. Ternary $\mathrm{FeO}$ vs. $\mathrm{TiO}_{2}$ vs. $\mathrm{Fe}_{2} \mathrm{O}_{3}$ diagram (Akimoto and Katsura, 1959) showing the main solid solutions of Fe-Ti oxides. Discussion in text.

Table 3. Analysis and formulae of representative ilmenite.

\begin{tabular}{|c|c|c|c|c|c|c|c|c|c|c|}
\hline Sample & $\begin{array}{l}\text { FU17 } \\
\text { MP C }\end{array}$ & $\begin{array}{l}\text { FU17 } \\
\text { MP C }\end{array}$ & $\begin{array}{l}\text { FU17 } \\
\text { MP C }\end{array}$ & $\begin{array}{l}\text { HL012a } \\
\text { MP C }\end{array}$ & $\begin{array}{l}\text { HL012a } \\
\text { MP C }\end{array}$ & $\begin{array}{c}\text { HLO04c } \\
\text { MP C }\end{array}$ & $\begin{array}{l}\text { HL004c } \\
\text { MP C }\end{array}$ & $\begin{array}{l}\text { HLO04c } \\
\text { MP C }\end{array}$ & $\begin{array}{l}\text { HLO04b } \\
\text { MP C }\end{array}$ & $\begin{array}{l}\text { LH05 } \\
\text { MP C }\end{array}$ \\
\hline \multicolumn{11}{|c|}{ Component } \\
\hline $\mathrm{SiO}_{2}$ & 0.010 & 0.040 & 0.000 & 0.020 & 0.000 & 0.040 & 0.050 & 0.050 & 0.030 & 0.290 \\
\hline $\mathrm{TiO}_{2}$ & 47.970 & 47.450 & 47.860 & 49.330 & 48.930 & 48.280 & 48.330 & 47.620 & 48.780 & 49.750 \\
\hline $\mathrm{Al}_{2} \mathrm{O}_{3}$ & 0.310 & 0.290 & 0.280 & 0.140 & 0.190 & 0.240 & 0.270 & 0.280 & 0.150 & 0.160 \\
\hline $\mathrm{FeOt}$ & 48.120 & 48.370 & 48.340 & 46.930 & 47.340 & 47.810 & 47.910 & 47.580 & 46.970 & 45.960 \\
\hline $\mathrm{MnO}$ & 0.440 & 0.390 & 0.370 & 0.460 & 0.420 & 0.450 & 0.440 & 0.390 & 0.460 & 0.480 \\
\hline $\mathrm{MgO}$ & 1.830 & 1.530 & 1.600 & 1.280 & 1.310 & 1.290 & 1.440 & 1.350 & 0.910 & 1.590 \\
\hline $\mathrm{CaO}$ & 0.170 & 0.140 & 0.070 & 0.030 & 0.080 & 0.120 & 0.120 & 0.150 & 0.000 & 0.120 \\
\hline Total & 98.840 & 98.170 & 98.520 & 98.190 & 98.270 & 98.230 & 98.560 & 97.420 & 97.300 & 98.350 \\
\hline \multicolumn{11}{|c|}{ Cations based on 4 oxygen } \\
\hline $\mathrm{Si}$ & 0.000 & 0.002 & 0.000 & 0.001 & 0.000 & 0.002 & 0.003 & 0.003 & 0.002 & 0.015 \\
\hline $\mathrm{Ti}$ & 1.862 & 1.859 & 1.867 & 1.918 & 1.905 & 1.886 & 1.880 & 1.876 & 1.919 & 1.918 \\
\hline $\mathrm{Al}$ & 0.019 & 0.018 & 0.017 & 0.008 & 0.011 & 0.015 & 0.018 & 0.017 & 0.009 & 0.010 \\
\hline $\mathrm{Fe}(\mathrm{ii})$ & 2.076 & 2.107 & 2.096 & 2.029 & 2.049 & 2.076 & 2.071 & 2.084 & 2.054 & 1.970 \\
\hline $\mathrm{Mn}$ & 0.019 & 0.017 & 0.016 & 0.020 & 0.019 & 0.020 & 0.019 & 0.017 & 0.020 & 0.021 \\
\hline $\mathrm{Mg}$ & 0.141 & 0.119 & 0.124 & 0.099 & 0.101 & 0.100 & 0.111 & 0.106 & 0.071 & 0.122 \\
\hline $\mathrm{Ca}$ & 0.009 & 0.008 & 0.004 & 0.002 & 0.005 & 0.006 & 0.007 & 0.009 & 0.000 & 0.007 \\
\hline Cat sum & 4.127 & 4.130 & 4.124 & 4.077 & 4.089 & 4.105 & 4.109 & 4.112 & 4.075 & 4.062 \\
\hline
\end{tabular}

MP: micro-phenocryst; C: core. 
the 6.1 to 10.3 range. Eu shows a very slightly negative anomaly with $\mathrm{Eu} / \mathrm{Eu}^{*}$ values of 0.92 to 0.94 .

Table 4. Representative analysis and formulae of olivine.

\begin{tabular}{l|c|c|c|c}
\hline Sample & FU 17 & FU 17 & FU 250 & FU 250 \\
P C & MP C & MP C \\
\hline $\mathrm{SiO}_{2}$ & 34.840 & 34.890 & 31.570 & 31.730 \\
\hline $\mathrm{TiO}_{2}$ & 0.070 & 0.080 & 0.260 & 0.120 \\
\hline $\mathrm{Al}_{2} \mathrm{O}_{3}$ & 0.040 & 0.050 & 0.020 & 0.000 \\
\hline $\mathrm{FeO}_{\mathrm{t}}$ & 33.960 & 34.010 & 54.020 & 53.410 \\
\hline $\mathrm{CaO}$ & 0.330 & 0.390 & 0.380 & 0.350 \\
\hline $\mathrm{MnO}$ & 0.450 & 0.480 & 0.920 & 0.830 \\
\hline $\mathrm{MgO}$ & 28.270 & 27.960 & 12.230 & 12.690 \\
\hline $\mathrm{NiO}$ & 0.060 & 0.070 & 0.010 & 0.000 \\
\hline $\mathrm{Total}$ & 98.020 & 97.930 & 99.420 & 99.147 \\
\hline \multicolumn{5}{|c|}{ Cations based on 4 oxygen } \\
\hline $\mathrm{Si}$ & 0.990 & 0.993 & 0.988 & 0.992 \\
\hline $\mathrm{Ti}$ & 0.002 & 0.002 & 0.006 & 0.003 \\
\hline $\mathrm{Al}$ & 0.001 & 0.002 & 0.001 & 0.000 \\
\hline $\mathrm{Fe}(\mathrm{ii})$ & 0.807 & 0.809 & 1.414 & 1.396 \\
\hline $\mathrm{Mn}$ & 0.011 & 0.012 & 0.024 & 0.022 \\
\hline $\mathrm{Mg}$ & 1.197 & 1.186 & 0.571 & 0.592 \\
\hline $\mathrm{Ni}$ & 0.001 & 0.002 & 0.000 & 0.000 \\
\hline $\mathrm{Ca}$ & 0.010 & 0.012 & 0.013 & 0.012 \\
\hline $\mathrm{Cat} \mathrm{sum}$ & 3.019 & 3.018 & 3.017 & 3.017 \\
\hline & 59.430 & 59.107 & 28.407 & 29.434 \\
\hline $\mathrm{Fo}$ & & & \\
\hline $\mathrm{Pi}$ & \multicolumn{5}{|c|}{ End-member (\%) } \\
\hline
\end{tabular}

P: phenocryst; MP: micro-phenocryst; C: core.

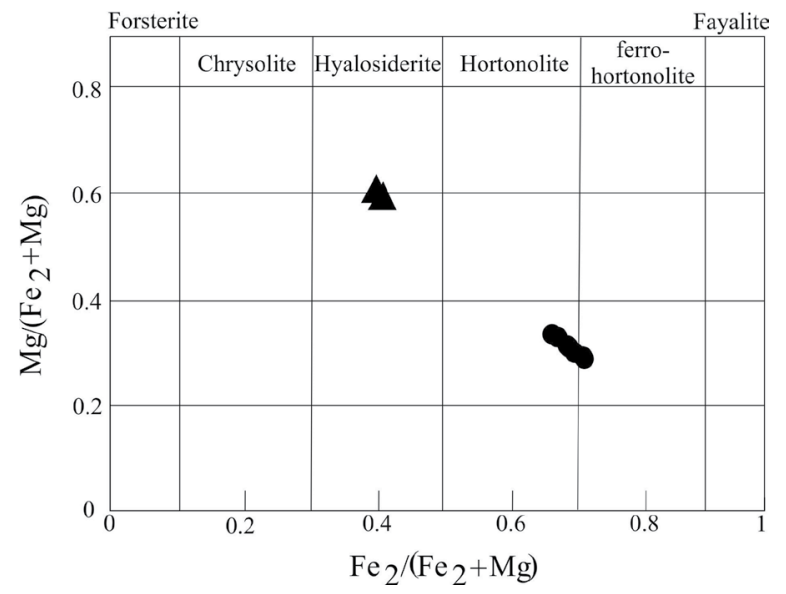

Source: modified from Sarmento et al. (2017).

Figure 13. Compositional variation of olivine from samples FU017 (full triangle), FU250 and LHO5 (full circle).
The multi-elemental distribution patterns normalized to primitive mantle show negative $\mathrm{Nb}$ anomalies, also observed for all high- and low-Ti tholeiites of the PCMP. The $(\mathrm{Rb} / \mathrm{Ba})_{\mathrm{PM}}$ ratios $<1$ (varying from $\mathrm{X}$ to $\mathrm{Y}$ ) is an indicative that the investigated basalt flows were not affected by low-pressure crustal contamination processes (e.g., Peate 1997, Marques et al. 1999, Marques et al. 2017).

\section{DISCUSSION}

In the Lower Cretaceous, the north and northeast edge of the Paraná Basin was delimited by topographically elevated terrains, known as Alto Paranaíba Arch, whose palaeorelief was highly irregular. These peculiarities determined the design and characteristics of the sedimentary and volcanic deposits. In such peridesertic region, occasional aqueous flows generated alluvial fan deposits and/or fluvio-lacustrine systems and, in addition, allowed the occurrence of pillow lavas. These characteristics - together with the broad domain of entablature on colonnades, very fine textured basalts, mesostasis with significant amount of glass and fossil records in contemporaneous sediments - are indicative of a more humid environment than the dominant in the rest of the PCMP. On the other hand, the predominance of intertrapped aeolian sandstone lenses in thin basalt flows suggests irregular topography and peripheral location.

Under microscopy, thin sections of entablature show abundant microlites and frequent plagioclase with swallowtail-like texture, opaque minerals with skeletal texture and volcanic glass in mesostasis. These characteristics are less frequent in thin-sections of colonnade samples, indicating a less quick cooling rate for the last one.
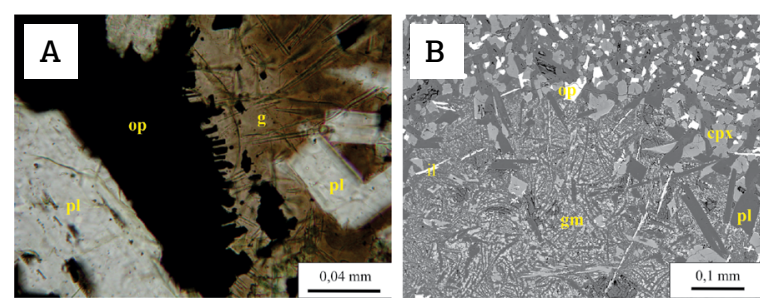

Pl: plagioclase; cpx: clinopyroxene; op: opaque mineral; il: ilmenite; gm: glassy mesostasis; g: glass.

Figure 14. (A) Typical example of vitreous mesostasis in the devitrification process; crystallites of clinopyroxene and plagioclase in plumose texture are abundant and associated with skeletal oxide crystals; (B) back-scattered image showing mesostasis with crystalites of plagioclase, pyroxene and opaque minerals. 
Table 5. Whole-rock analysis of 22 basalt samples and CIPW Norm data.

\begin{tabular}{|c|c|c|c|c|c|c|c|c|c|c|c|}
\hline Sample & HLOO1 & HL003A & HL003D & HL004C & HL004E & HL004J* & HL011B* & HL011C & HL013A* & HL013B & HLA1 \\
\hline Long (-) & 7.6235 & 48.2108 & 48.2108 & 48.2136 & 48.2136 & 48.2136 & 48.3241 & 48.3241 & 48.3240 & 48.3240 & 48.2240 \\
\hline Lat & 9.2819 & 8.7259 & 8.7259 & 12.8183 & 12.8183 & 12.8183 & 54 & 54 & 3 & 863 & 18.7289 \\
\hline \multicolumn{12}{|c|}{ Major elements (wt. \%) } \\
\hline $\mathrm{SiO}_{2}$ & 49.7600 & 47.6100 & 49.5800 & 49.7500 & 47.7100 & 49.9300 & 50.5300 & 49.8000 & 50.9000 & 49.7300 & 47.5900 \\
\hline $\mathrm{TiO}_{2}$ & 2100 & 3700 & 2400 & 5400 & 5600 & 61 & 0 & 5600 & 100 & .5200 & 3.5700 \\
\hline $\mathrm{Al}_{2} \mathrm{O}_{3}$ & 12.6200 & 11.9800 & 12.6600 & 12.5000 & 12.6700 & 12.5300 & 12.5900 & 12.4800 & 12.7500 & 12.3600 & 12.5000 \\
\hline $\mathrm{Fe}_{2} \mathrm{O}_{3}(\mathrm{t})$ & 14.2900 & 18.4800 & 14.2700 & 14.6200 & 14.7700 & 14.8400 & 14.3300 & 14.7800 & 14.5200 & 14.7400 & 15.3100 \\
\hline $\mathrm{CaO}$ & 9.7700 & 8.8600 & 9.8400 & 9.2900 & 9.6600 & 9.4000 & 9.8500 & 9.3600 & 9.6200 & 9.2900 & 9.0000 \\
\hline $\mathrm{MgO}$ & 5.4300 & 4.6100 & 5.3300 & 4.8200 & 4.9300 & 4.7200 & 4.8200 & 4.7700 & 5.0300 & 4.8000 & 4.8000 \\
\hline $\mathrm{Na}_{2} \mathrm{O}$ & 2.4700 & 2.7800 & 6600 & 2.8700 & 2.3500 & 2.8800 & 2.8900 & 2.8200 & 2.8600 & 2.8300 & 2.6400 \\
\hline $\mathrm{K}_{2} \mathrm{O}$ & 0.9900 & 0.7700 & 8000 & 0.8400 & 1.4900 & 0.8500 & 0.8200 & 0.9300 & 0.8900 & 0.9000 & 1.3000 \\
\hline $\mathrm{P}_{2} \mathrm{O}_{5}$ & 0.3600 & 0.4200 & 0.3700 & 0.4400 & 0.4300 & 0.4300 & 0.4700 & 0.4500 & 0.4300 & 0.4400 & 0.4500 \\
\hline $\mathrm{MnO}$ & 0.1900 & 0.2400 & 0.1800 & 0.2000 & 0.1800 & 0.2000 & 0.2200 & 0.1900 & 0.2200 & 0.1800 & 0.2100 \\
\hline LOI & 0.8800 & 0100 & .0400 & 1.1100 & 2.2400 & 1.1500 & 0.9900 & 0.9500 & 0.9000 & 1.2200 & 2.6300 \\
\hline Total & 99.9700 & 00.1300 & 999700 & 00 & 99.9900 & 100.5400 & 0.0900 & 100.0900 & 101.8300 & 00.0100 & 100.0000 \\
\hline \multicolumn{12}{|c|}{ CIPW Norm (\%) } \\
\hline $\mathrm{qz}$ & 0.0000 & 0.0000 & 1.3900 & 1.8200 & 0.0000 & 1.2100 & 2.1200 & 1.7400 & 2.1300 & 1.8100 & 0.0000 \\
\hline or & 9.7600 & 4.8000 & 9000 & 5.2000 & 9.3500 & 5.2000 & 5.0000 & 5.7500 & 5.3500 & 5.6000 & 8.2000 \\
\hline$a b$ & 23.1000 & 5.1000 & 24.8500 & 20.7500 & 22.3500 & 26.8500 & 26.7000 & 26.3500 & 6.2500 & 26.5000 & 25.2000 \\
\hline an & 21.2000 & 18.7800 & 21.0500 & 19.5000 & 20.6800 & 18.8800 & 19.5300 & 19.4300 & 19.7300 & 19.2000 & 19.4800 \\
\hline $\mathrm{di}$ & 21.3200 & 19.4800 & 21.6800 & 22.8800 & 21.6000 & 23.2000 & 22.1200 & 20.6800 & 20.9200 & 20.7600 & 19.8400 \\
\hline en & 10.8400 & 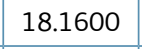 & 1 & 15.3800 & 0 & 16.4000 & 0 & 0 & 0 & 0 & 00 \\
\hline ol & 2700 & 3.8700 & 0000 & 0000 & .5300 & 0.0000 & 0.0000 & 0.0000 & 0.0000 & 0.0000 & 2.4000 \\
\hline $\mathrm{mt}$ & 2.0300 & 2.6400 & 2.0300 & 2.7800 & 2.1300 & 2.1000 & 2.0100 & 2.1000 & 2.0300 & 2.1000 & 2.2200 \\
\hline il & 1.0000 & 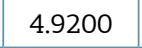 & 1.7000 & 5.100 & .2600 & 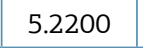 & . & 5.1800 & .4000 & 5.1400 & 5.2800 \\
\hline ap & 8000 & 9300 & 8300 & 9500 & 9600 & 0.9400 & 0100 & 0.9900 & .9300 & 0.9600 & 1.0100 \\
\hline tota & .9800 & 5800 & 3900 & 0.6000 & 100.0200 & 100.0000 & 100.0100 & 100.0200 & 100.0400 & 100.0100 & 100.0100 \\
\hline \multicolumn{12}{|c|}{ Trace elements (ppm) } \\
\hline $\mathrm{Zn}$ & 4.0000 & 107.0000 & 103.0000 & 108.0000 & 105.0000 & 117.0000 & 112.0000 & 107.0000 & 113.0000 & 101.0000 & 116.0000 \\
\hline $\mathrm{Cu}$ & 8.0000 & 163.0000 & 180.0000 & 164.0000 & 171.0000 & 185.0000 & 188.0000 & 161.0000 & 186.0000 & 162.0000 & 99.0000 \\
\hline $\mathrm{Cr}$ & 4.0000 & 7.0000 & 121.0000 & 00 & .0000 & - & - & 00 & 00 & Do & 12.0000 \\
\hline $\mathrm{Ni}$ & 66.0000 & 53.0000 & 66.0000 & 60.0000 & 51.0000 & 59.0000 & 64.0000 & 53.0000 & 60.0000 & 50.0000 & 22.0000 \\
\hline $\mathrm{Ba}$ & 0.0000 & 402.0000 & 347.0000 & 422.0000 & 412.0000 & 490.0000 & 396.0000 & 426.0000 & 394.0000 & 435.0000 & 498.0000 \\
\hline $\mathrm{Cc}$ & 000 & 0000 & 0000 & 00 & 0000 & 00 & 00 & 000 & 000 & .0000 & 38.0000 \\
\hline Cs & - & - & - & 3200 & - & 0.3300 & 0.2500 & - & 0.2600 & - & - \\
\hline $\mathrm{Ga}$ & 20.0000 & 20.0000 & 20.0000 & 22.5000 & 20.0000 & 22.4000 & 22.6000 & 20.0000 & 22.8000 & 21.0000 & 19.0000 \\
\hline $\mathrm{Hf}$ & - & - & - & oo & 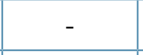 & 300 & 400 & - & 700 & - & - \\
\hline $\mathrm{Nb}$ & 20.0000 & 20.0000 & 19.0000 & 22.3600 & 19.0000 & 20.9100 & 21.7100 & 20.0000 & 20.1200 & 20.1200 & 22.0000 \\
\hline $\mathrm{Rb}$ & 23.0000 & 20.0000 & 20.0000 & 20.1000 & 28.0000 & 23.0000 & 22.9000 & 21.0000 & 21.7000 & 20.0000 & 18.0000 \\
\hline Sn & - & - & - & 1.5000 & - & 1.1000 & 0.9000 & - & 0.9000 & - & - \\
\hline $\mathrm{Sr}$ & 375.0000 & 380.0000 & 388.0000 & 381.1000 & 403.0000 & 480.0000 & 491.0000 & 377.0000 & 488.0000 & 377.0000 & 405.0000 \\
\hline Th & - & - & - & 0 & - & 0 & 0 & - & 0 & - & - \\
\hline $\mathrm{U}$ & - & - & - & 0.7100 & - & 0.6900 & 0.7800 & - & 0.6400 & - & - \\
\hline
\end{tabular}


Table 5. Continuation.

\begin{tabular}{|c|c|c|c|c|c|c|c|c|c|c|c|}
\hline Sample & HLOO1 & HL003A & HL003D & HL004C & HL004E & HL004J* & HL011B* & HL011C & HL013A* & HL013B & HLA1 \\
\hline Long (-) & 47.6235 & 8.2108 & 48.2108 & 48.2136 & 48.2136 & 48.2136 & 48.3241 & 48.3241 & 48.3240 & 48.3240 & 48.2240 \\
\hline Lat (-) & 19.2819 & 18.7259 & 18.7259 & 12.8183 & 12.8183 & 12.8183 & 18.8754 & 18.8754 & 18.8863 & 18.8863 & 18.7289 \\
\hline \multicolumn{12}{|c|}{ Major elements (wt. \%) } \\
\hline $\mathrm{Zr}$ & 175.0000 & 197.0000 & 176.0000 & 198.0000 & 191.0000 & 229.0000 & 242.0000 & 196.0000 & 246.0000 & 198.000 & 230.000 \\
\hline $\mathrm{Y}$ & 27.0000 & 29.0000 & 26.0000 & 30.9700 & 29.0000 & 29.9100 & 32.0100 & 29.0000 & 30.6100 & 29.000 & 31.0000 \\
\hline $\mathrm{La}$ & 12.0000 & 25.0000 & 25.0000 & 32.5000 & 29.0000 & 30.3000 & 40.3000 & 24.0000 & 33.9000 & 31.000 & 30.0000 \\
\hline $\mathrm{Ce}$ & 74.0000 & 73.0000 & 66.0000 & 81.0000 & 73.0000 & 67.5000 & 74.3000 & 67.0000 & 68.8000 & 73.000 & 83.0000 \\
\hline $\operatorname{Pr}$ & - & - & - & 8.7900 & - & 8.6600 & 9.2900 & - & 8.7000 & - & - \\
\hline $\mathrm{Nd}$ & - & - & - & 37.4000 & - & 37.2000 & 39.6000 & - & 37.9000 & - & - \\
\hline $\mathrm{Sm}$ & - & - & - & 8.1000 & - & 8.2000 & 8.5000 & - & 8.2000 & - & - \\
\hline $\mathrm{Eu}$ & - & - & - & 2.5300 & - & 2.5300 & 2.6100 & - & 2.5100 & - & - \\
\hline Gd & - & - & - & 8.2200 & - & 8.0400 & 8.4500 & - & 8.1200 & - & - \\
\hline $\mathrm{Tb}$ & - & - & - & 1.2000 & - & 1.1900 & 1.2500 & - & 1.1800 & - & - \\
\hline Dy & - & - & - & 6.6400 & - & 6.5600 & 6.8200 & - & 6.6000 & - & - \\
\hline Ho & - & - & - & 1.2600 & - & 1.2500 & 1.2900 & - & 1.2500 & - & - \\
\hline Er & - & - & - & 3.4600 & - & 3.3300 & 3.5500 & - & 3.3800 & - & - \\
\hline $\mathrm{Tm}$ & - & - & - & 0.4800 & - & 0.4600 & 0.4600 & - & 0.4400 & - & - \\
\hline $\mathrm{Yb}$ & - & - & - & 2.8000 & - & 2.7000 & 2.8000 & - & 2.7000 & - & - \\
\hline $\mathrm{Lu}$ & - & - & - & 0.4100 & - & 0.3900 & 0.4200 & - & 0.3900 & - & - \\
\hline Sample & HLA7 & FU17* & FS065 & FS066 & FS129 & FS229 & FS236 & FS252 & LHO3 & LHO4 & LHO5 \\
\hline Long (-) & 48.2264 & 47.9590 & 47.4383 & 47.4529 & 47.4402 & 47.3380 & 47.3674 & 47.4322 & 48.2191 & 48.2192 & 48.2193 \\
\hline Lat (-) & 18.7118 & 19.9550 & 19.6112 & 19.6050 & 19.9639 & 19.7701 & 19.7733 & 19.8493 & 7262 & 18.7261 & 18.7260 \\
\hline \multicolumn{12}{|c|}{ Major elements (wt. \%) } \\
\hline $\mathrm{SiO}_{2}$ & 49.7100 & 50.1200 & 50.5300 & 50.6800 & 49.9300 & 51.4200 & 50.8900 & 50.4800 & 46.7300 & 50.7000 & 49.3200 \\
\hline $\mathrm{TiO}_{2}$ & 3.2300 & 3.5400 & 3.8800 & 3.9000 & 3.9700 & 3.6400 & 3.6300 & 3.9100 & 3.5900 & 3.4600 & 3.2500 \\
\hline $\mathrm{Al}_{2} \mathrm{O}_{3}$ & 12.6700 & 12.5400 & 11.8700 & 11.9400 & 12.6300 & 12.1600 & 12.2100 & 11.8500 & 12.6100 & 12.1100 & 12.5700 \\
\hline $\mathrm{Fe}_{2} \mathrm{O}_{3}(\mathrm{t})$ & 14.4200 & 14.6800 & 15.8500 & 14.9400 & 14.5000 & 15.0100 & 15.2800 & 15.7300 & 15.6800 & 15.0200 & 14.7700 \\
\hline $\mathrm{CaO}$ & 9.8000 & 9.4000 & 8.0400 & 8.2200 & 8.1400 & 8.0700 & 8.1800 & 8.0300 & 9.2500 & 8.3300 & 9.7900 \\
\hline $\mathrm{MgO}$ & 5.4900 & 4.4600 & 3.9200 & 4.1200 & 4.3500 & 4.0300 & 4.1800 & 3.9400 & 5.0200 & 3.9300 & 5.4700 \\
\hline $\mathrm{Na}_{2} \mathrm{O}$ & 2.5700 & 2.6900 & 2.6300 & 2.8300 & 3.0000 & 2.6800 & 2.7800 & 2.6300 & 2.4900 & 3.0100 & 2.5300 \\
\hline $\mathrm{K}_{2} \mathrm{O}$ & 0.9400 & 1.0400 & 1.6400 & 1.4900 & 1.4900 & 1.5200 & 1.4900 & 1.5300 & 1.0600 & 1.1700 & 1.1700 \\
\hline $\mathrm{P}_{2} \mathrm{O}_{5}$ & 0.3600 & 0.4400 & 0.6600 & 0.7900 & 0.6500 & 0.5100 & 0.5100 & 0.6600 & 0.4600 & 0.4500 & 0.3700 \\
\hline $\mathrm{MnO}$ & 0.1800 & 100 & 0.2200 & 0.2000 & 0.2000 & 0.2000 & 0.2000 & 0.2200 & 0.2200 & 0.1900 & 0.1900 \\
\hline LOI & 0.6400 & 0.1500 & 0.9500 & 0.9200 & 1.1300 & 0.7400 & 0.6600 & 0.9800 & 2.9000 & 1.5800 & 0.8200 \\
\hline Total & 100.0100 & 99.2700 & 100.1900 & 100.0300 & 99.9900 & 99.9800 & 100.0100 & 99.9600 & 100.0100 & 99.9500 & 99.9800 \\
\hline \multicolumn{12}{|c|}{ CIPW Norm (\%) } \\
\hline $\mathrm{qz}$ & 0.5200 & 2.2600 & 4.0200 & 2.0600 & 1.2300 & 4.6700 & 3.3400 & 1.9200 & 0.0000 & 3.1900 & 0.9000 \\
\hline or & 5.8000 & 6.4000 & 9.7000 & 9.2500 & 9.200 & 9.4000 & 9.1500 & 9.5500 & 6.6500 & 7.3000 & 5.5500 \\
\hline $\mathrm{ab}$ & 23.9000 & 25.1000 & 22.1000 & 26.6000 & 27.8200 & 25.2500 & 26.0000 & 24.8500 & 23.8500 & 28.4500 & 23.6000 \\
\hline an & 20.9500 & 19.8000 & 16.4000 & 16.1500 & 17.3000 & 17.3500 & 17.1800 & 16.8300 & 21.4000 & 16.9000 & 21.0800 \\
\hline $\mathrm{di}$ & 23.5200 & 20.5200 & 17.3300 & 21.2400 & 19.9200 & 16.8000 & 17.3200 & 18.2600 & 19.4000 & 18.8800 & 21.4000 \\
\hline en & 18.3400 & 17.7800 & 19.1000 & 16.8800 & 16.1600 & 17.9800 & 18.4200 & 18.6400 & 17.2000 & 17.1000 & 19.8400 \\
\hline
\end{tabular}


Table 5. Continuation.

\begin{tabular}{|c|c|c|c|c|c|c|c|c|c|c|c|}
\hline Sample & HLA7 & FU17* & FS065 & FS066 & FS129 & FS229 & FS236 & FS252 & LHO3 & LHO4 & LHO5 \\
\hline Long (-) & 48.2264 & 47.9590 & 47.4383 & 47.4529 & 47.4402 & 47.3380 & 47.3674 & 47.4322 & 48.2191 & 48.2192 & 48.2193 \\
\hline Lat (-) & 18.7118 & 19.9550 & 19.6112 & 19.6050 & 19.9639 & 19.7701 & 19.7733 & 19.8493 & 18.7262 & 18.7261 & 18.7260 \\
\hline ol & 0.0000 & 0.0000 & 0.0000 & 0.0000 & 0.0000 & 0.0000 & 0.0000 & 0.0000 & 2.8500 & 0.0000 & 0.0000 \\
\hline $\mathrm{mt}$ & 2.0400 & 2.0700 & 2.9100 & 0.0500 & 2.0600 & 2.1500 & 2.1800 & 2.2500 & 2.2800 & 2.1500 & 2.0900 \\
\hline il & 4.6200 & 5.1200 & 6.4300 & 5.6800 & 5.7800 & 5.3000 & 5.2200 & 5.7200 & 5.3400 & 5.0800 & 4.7200 \\
\hline ap & 0.8000 & 0.9600 & 2.0000 & 1.7500 & 1.4200 & 1.1200 & 1.1200 & 1.4400 & 1.0400 & 0.9600 & 0.8300 \\
\hline Total & 100.4900 & 100.0100 & 99.9900 & 99.6600 & 100.8900 & 100.0200 & 99.9300 & 99.4600 & 100.0100 & 100.0100 & 100.0100 \\
\hline \multicolumn{12}{|c|}{ Trace elements (ppm) } \\
\hline $\mathrm{Zn}$ & 98.0000 & 118.0000 & 139.0000 & 125.0000 & 125.0000 & 120.0000 & 109.0000 & 121.0000 & 114.0000 & 105.0000 & 98.0000 \\
\hline $\mathrm{Cu}$ & 179.0000 & 188.0000 & 136.0000 & 60.0000 & 85.0000 & 63.0000 & 58.0000 & 138.0000 & 88.0000 & 119.0000 & 176.0000 \\
\hline $\mathrm{Cr}$ & 126.0000 & & 18.0000 & 6.0000 & 30.0000 & 17.0000 & 15.0000 & 10.0000 & 16.0000 & 9.0000 & 116.0000 \\
\hline $\mathrm{Ni}$ & 66.0000 & 62.0000 & 20.0000 & 21.0000 & 43.0000 & 21.0000 & 20.0000 & 23.0000 & 20.0000 & 22.0000 & 64.0000 \\
\hline $\mathrm{Ba}$ & 383.0000 & 458.0000 & 517.0000 & 528.0000 & 583.0000 & 500.0000 & 501.0000 & 497.0000 & 458.0000 & 539.0000 & 368.0000 \\
\hline Co & 42.0000 & 40.3000 & 38.00000 & 38.0000 & 39.0000 & 38.0000 & 35.0000 & 34.0000 & 42.0000 & 38.0000 & 38.0000 \\
\hline Cs & - & 0.2700 & - & - & - & - & - & - & - & - & - \\
\hline $\mathrm{Ga}$ & 20.0000 & 22.4000 & 20.0000 & 20.0000 & 21.0000 & 21.0000 & 21.0000 & 21.0000 & 20.0000 & 21.0000 & 19.0000 \\
\hline Hf & - & 5.7800 & - & - & - & - & - & - & - & - & - \\
\hline $\mathrm{Nb}$ & 19.0000 & 19.6400 & 27.00000 & 25.0000 & 26.0000 & 22.0000 & 21.0000 & 28.0000 & 22.0000 & 21.0000 & 17.0000 \\
\hline $\mathrm{Rb}$ & 21.0000 & 18.5000 & 32.00000 & 29.0000 & 30.0000 & 28.0000 & 26.0000 & 31.0000 & 14.0000 & 21.0000 & 21.0000 \\
\hline $\mathrm{Sn}$ & - & 0.9000 & - & - & - & - & - & - & - & - & - \\
\hline $\mathrm{Sr}$ & 376.0000 & 475.0000 & 394.0000 & 471.0000 & 504.0000 & 378.0000 & 382.0000 & 386.0000 & 392.0000 & 393.0000 & 377.0000 \\
\hline Th & - & 2.9000 & - & - & - & - & - & - & - & - & - \\
\hline $\mathrm{U}$ & - & 0.6400 & - & - & - & - & - & - & - & - & - \\
\hline $\mathrm{V}$ & 423.0000 & 481.0000 & 397.00000 & 319.0000 & 417.0000 & 407.0000 & 390.0000 & 400.0000 & 464.0000 & 418.0000 & 421.0000 \\
\hline W & - & 1.4000 & - & - & - & - & - & - & - & - & - \\
\hline $\mathrm{Zr}$ & 175.00000 & 243.0000 & 243.0000 & 230.0000 & 234.0000 & 225.0000 & 225.0000 & 244.0000 & 228.0000 & 228.0000 & 171.0000 \\
\hline $\mathrm{Y}$ & 27.0000 & 30.3500 & 33.0000 & 32.0000 & 30.0000 & 31.0000 & 32.0000 & 32.0000 & 30.0000 & 31.0000 & 27.0000 \\
\hline $\mathrm{La}$ & 22.0000 & 32.2000 & 23.0000 & 35.0000 & 22.0000 & 23.0000 & 23.0000 & 27.0000 & 33.0000 & 31.0000 & 18.0000 \\
\hline $\mathrm{Ce}$ & 65.0000 & 67.9000 & 93.0000 & 98.0000 & 94.0000 & 95.0000 & 83.0000 & 114.0000 & 94.0000 & 91.0000 & 74.0000 \\
\hline $\operatorname{Pr}$ & - & 8.7300 & - & - & - & - & - & - & - & - & - \\
\hline $\mathrm{Nd}$ & - & 37.2000 & - & - & - & - & - & - & - & - & - \\
\hline $\mathrm{Sm}$ & - & 8.3000 & - & - & - & - & - & - & - & - & - \\
\hline $\mathrm{Eu}$ & - & 2.4900 & - & - & - & - & - & - & - & - & - \\
\hline $\mathrm{Gd}$ & - & 7.9800 & - & - & - & - & - & - & - & - & - \\
\hline $\mathrm{Tb}$ & - & 1.1600 & - & - & - & - & - & - & - & - & - \\
\hline Dy & - & 6.6700 & - & - & - & - & - & - & - & - & - \\
\hline Ho & - & 1.2600 & - & - & - & - & - & - & - & - & - \\
\hline $\mathrm{Er}$ & - & 3.3000 & - & - & - & - & - & - & - & - & - \\
\hline $\mathrm{Tm}$ & - & 0.4500 & - & - & - & - & - & - & - & - & - \\
\hline $\mathrm{Yb}$ & - & 2.7000 & - & - & - & - & - & - & - & - & - \\
\hline $\mathrm{Lu}$ & - & 0.4000 & - & - & - & - & - & - & - & - & - \\
\hline
\end{tabular}

Source: Fujimori, 1990; HL and LH: Uberlândia/Araguari region; FU: Uberaba region; FS: Sacramento region; qz: quartz; or: orthoclase; ab: albite; an: anorthite; di: diopside; en: enstatite; ol: olivine; mt: magnetite; il: ilmenite; ap: apatite; *analyzed by Geosol.

Trace and rare earth elements from HL004C were determined by Geosol. See text for details. 

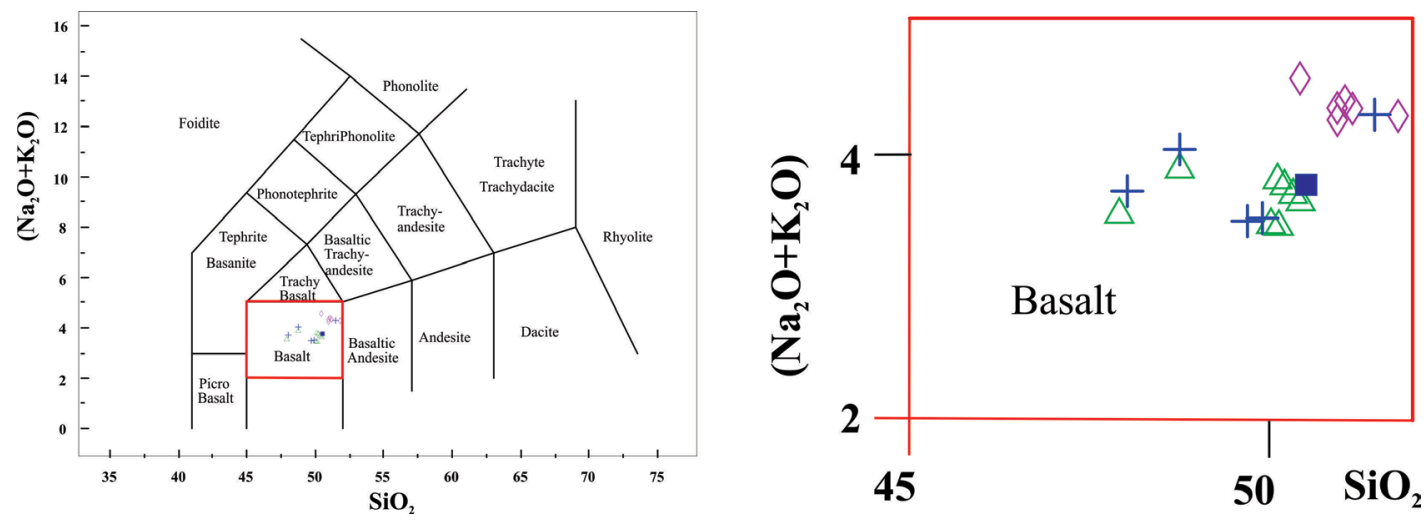

Empty diamonds: Sacramento; full square: Uberaba; empty triangles: Uberlândia/Araguari and crosses: basalt flows related to pillow lavas.

Figure 15. Classification and chemical nomenclature of the studied samples. Total alkali-versus-silica (TAS) diagram (alkalis vs. $\mathrm{SiO}_{2}$ ), according to Le Bas et al. (1986).
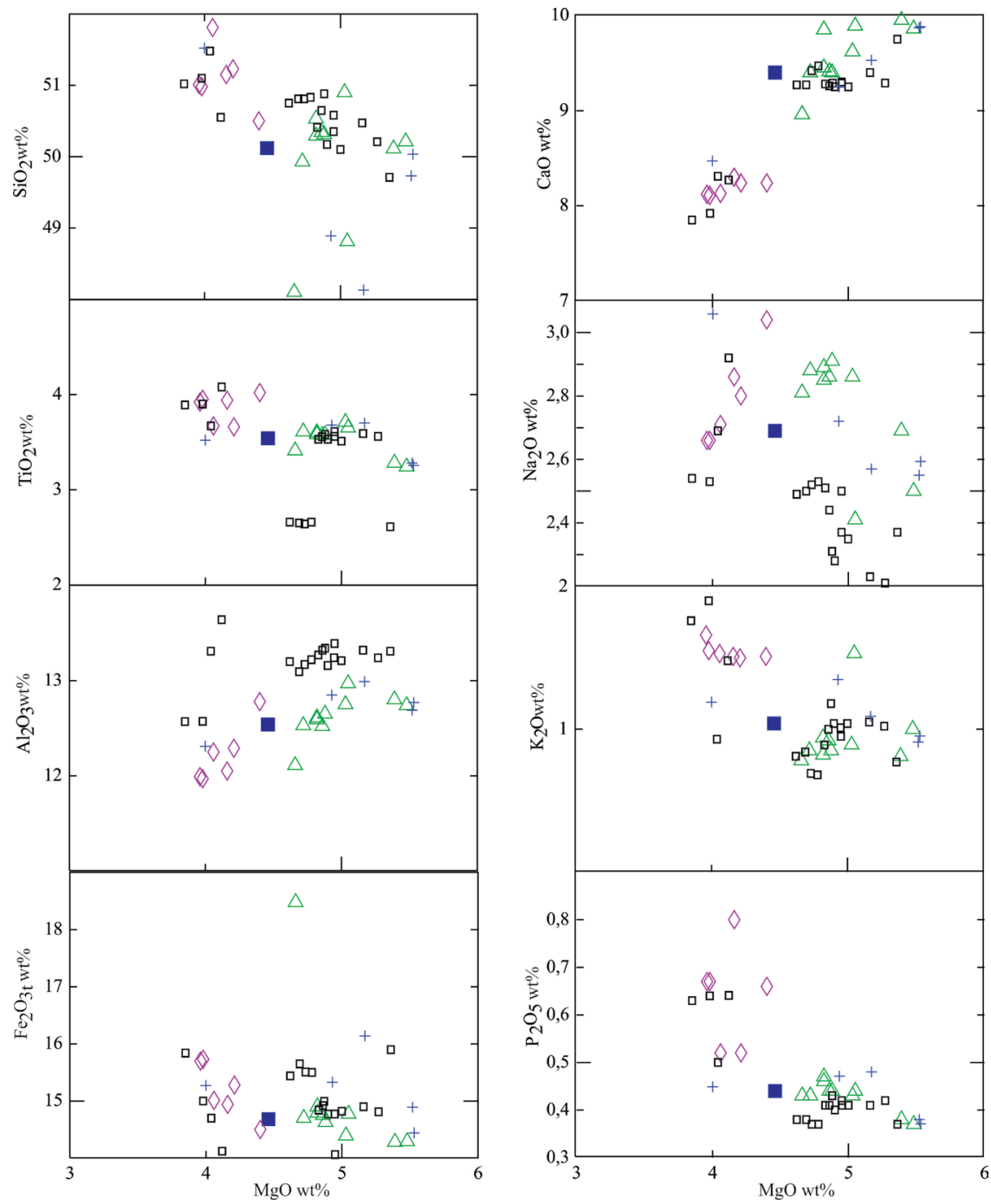

Empty squares: 18 samples from the Triângulo Mineiro and northeast of São Paulo (Rocha Junior et al., 2013); empty diamonds: Sacramento; full square: Uberaba; empty triangles: Uberlândia/Araguari and crosses: basalt flows related to pillow lavas).

Figure 16. Diagrams for major and minor elements vs. MgO. 
An unusual feature is the presence of inverted or alternating zoning from the core to the edge in some plagioclase and pyroxene crystals. According to Vernon (2004, p. 139141 ), even though it has been produced in the laboratory, reverse discontinuous zoning is uncommon in igneous rocks. However, it could be produced by a rapidly induced temperature variation (caused by, for example, rapid movement of magma in a chamber, volcanic eruption, rapid release of volatiles in a water-saturated magma, or magma mixing). This author also discusses patchy zoning which, as stated by Vance (1965 apud Vernon 2004), is due to initial crystallization of relatively calcic plagioclase in a water-undersaturated magma at depth, that suffer a rapid decrease in confining pressure, causing resorption. A new crystallization of more sodic plagioclase begins to fill cavities in the nuclei
— forming pseudoinclusions — and enveloping it with a composition different from that of the previous zones. Not rarely, small inclusions (e.g., of glass or pyroxene) occur in the more sodium-rich patches, generated from trapped melt in the corroded core. Normal and reverse oscillatory zoning may also occur in clinopyroxene - generally oscillating between augite and subcalcic augite, — and is explained as the response to local diffusion limitations, as in the case of plagioclase. It should also be recorded that two pigeonitic cores were identified in pyroxene phenocrysts.

Still with respect to plagioclases, the overlaps between the compositions of groundmass and phenocrysts, illustrated in the ternary classification diagram Ab-An-Or (Fig. 7), suggest the simultaneous crystallization of both phenocrysts edges and groundmass (Rao et al. 2012).
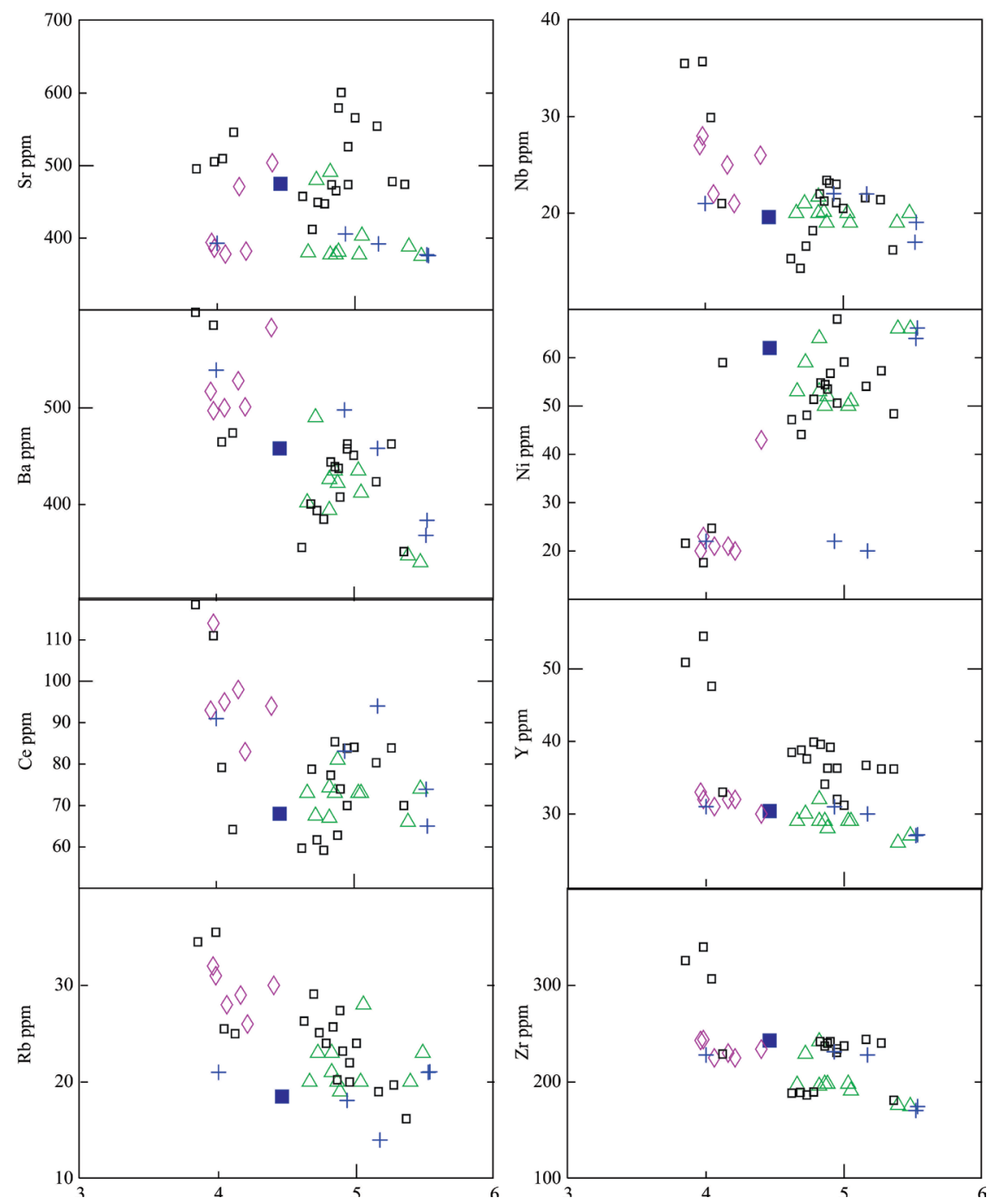

Empty squares: 18 samples from the Triângulo Mineiro and northeast of São Paulo (Rocha Junior et al., 2013); empty diamonds: Sacramento; fullsquare: Uberaba; empty triangles: Uberlândia/Araguari and crosses: basalt flows related to pillow lavas).

Figure 17. Diagrams for trace elements vs. MgO. 
Olivines, with hyalosiderite (Fo59), hortonolite and ferrohortonolite (Fo28) composition, were identified in samples from Uberaba and Uberlândia/Araguari regions. The current level of knowledge does not permit discussing the relationships/meaning between the basaltic flows with these distinct olivines. However, the data are in agreement with ones presented by Machado (2009) for magmas of the Pitanga type, in the northwest of the Province. This kind of record is present in olivine phenocrysts of lava flows from Linga area of the Eastern Deccan Volcanic Province. According to Ganguly et al. (2012), while the high iron content denotes a magma with much-evolved composition, the broad compositional spectrum of phenocrysts corroborates a changing crystallization condition in the predominant magmatic environment. More detailed studies are needed to test this hypothesis for Pitanga magma type.

These rocks are classified as basalts and have a tholeiitic character, with strong enrichment of iron in relation to alkalis and magnesium. Although the $\mathrm{TiO}_{2}$ content shows 3.7 $\mathrm{wt} \%$ in average, similar to Urubici magma type, the samples plot on the Pitanga field in the $\mathrm{Sr} v$ s. $\mathrm{TiO}_{2}$ diagram. Two specific fields are clear in major oxides / trace elements vs. $\mathrm{MgO}$ diagrams: one for less evolved rocks $(\mathrm{MgO}>4.65$ $\mathrm{wt} \%$ ) from the Uberlândia/Araguari region; and other one for those more evolved rocks from the Sacramento region $(\mathrm{MgO}<4.35 \mathrm{wt} \%)$, with the single sample of the Uberaba region in the intermediate area, between the two groups. Samples of the basalt flows related to pillow lavas plot scattered among the groups mentioned. Sample HL04, however, shows an enrichment in $\mathrm{SiO}_{2}, \mathrm{Na}_{2} \mathrm{O}$ and $\mathrm{Rb}$, and impoverishment in $\mathrm{CaO}$ and $\mathrm{MgO}$, which suggests alteration by water interaction. In general, there is a correspondence with Rocha-Júnior et al. (2013) data, although these exhibit lower values for $\mathrm{Na}_{2} \mathrm{O}$ and higher for $\mathrm{Al}_{2} \mathrm{O}_{3}$, suggesting the possibility of some analytical bias.

Heavy REE are depleted compared to light rare-earth elements $(L R E E)$ with $(\mathrm{La} / \mathrm{Lu})_{\mathrm{N}}$ between 8.04 to 9.93, and, although some enrichment in LREE is expected as a result of fractional crystallization, the high $(\mathrm{La} / \mathrm{Lu})_{\mathrm{N}}$ values are indicative of partial melting of a garnet peridotite, constraining the mantle source to depths greater than $80 \mathrm{~km}$ (Wilson 2007). Taking into account that $(\mathrm{Rb} / \mathrm{Ba})_{\mathrm{PM}}$ ratios are $<1$ in all analyzed basalts, suggesting that the magmas did not suffer crustal contamination during their ascension to surface, the $\mathrm{Nb}$ negative anomaly observed in the multi-elemental trace element patterns is a mantle source feature. According to Rocha-Júnior et al. $(2012,2013)$ the sources of PCMP basalts were affected by Neoproterozoic subductions (generating the depletion in $\mathrm{Nb}$ ) related with the Gondwana Assembly.
The trends observed for major, minor and trace elements in the variation diagrams (Figs. 16 and 17) are broadly compatible with fractional crystallization of clinopyroxene, plagioclase and Ti-magnetite. The slightly negative $\mathrm{Eu}$ anomalies $\left(\mathrm{Eu} / \mathrm{Eu}^{*}=0.92-0.94\right)$ in the REE distribution patterns reinforce plagioclase fractionation. Besides that, the geochemical data point to evolution involving at least two parental magmas, as evidenced by their distinct $\mathrm{Ba} / \mathrm{Zr}, \mathrm{Nb} / \mathrm{Zr}$ and $\mathrm{Nb} / \mathrm{Y}$ ratios (Fig. 19). One of them would generate the basalts of Sacramento, whereas the other one originated the Araguari/Uberlândia, Uberaba and Perdizes tholeiite group. It is noteworthy that the last group presents some variation in major, minor and trace elements, such as $\mathrm{TiO}_{2}, \mathrm{P}_{2} \mathrm{O}_{5}$, $\mathrm{Rb} / \mathrm{Sr}, \mathrm{Zr} / \mathrm{Nb}$, which is also suggestive of different parental magmas, but additional highly incompatible trace element data are necessary to corroborate this possibility.

\section{CONCLUDING REMARKS}

The northeast edge of the South American portion of the PEP is formed by heterogeneous lava packages with

Table 6. Classification of the basaltic rocks from the studied area according to Peate et al. (1992) parameters.

\begin{tabular}{l|c|c|c|c|c}
\hline Sample & $\mathbf{T i O}_{2}$ & Sr $\mathbf{p p m}$ & $\mathbf{T i} / \mathbf{Y}$ & $\mathbf{Z r} / \mathbf{Y}$ & Magma type \\
\hline HL001 & 3.24 & 375 & 740 & 6.48 & Pitanga \\
\hline HL003A & 3.41 & 380 & 703 & 6.79 & Pitanga \\
\hline HL003D & 3.28 & 388 & 753 & 6.77 & Pitanga \\
\hline HL004C & 3.58 & 381 & 764 & 7.07 & Pitanga \\
\hline HL004E & 3.65 & 403 & 689 & 6.59 & Pitanga \\
\hline HL004J & 3.61 & 480 & 722 & 7.66 & Pitanga \\
\hline HL0011B & 3.58 & 377 & 668 & 7.56 & Pitanga \\
\hline HL0011C & 3.60 & 377 & 741 & 6.76 & Pitanga \\
\hline HL0013A & 3.71 & 488 & 725 & 8.04 & Pitanga \\
\hline HL0013B & 3.57 & 377 & 738 & 6.83 & Pitanga \\
\hline HLA1 & 3.67 & 405 & 645 & 7.42 & Pitanga \\
\hline HLA7 & 3.25 & 376 & 741 & 6.48 & Pitanga \\
\hline FU17 & 3.54 & 475 & 698 & 8.01 & Pitanga \\
\hline FS 065 & 3.88 & 394 & 703 & 7.36 & Pitanga \\
\hline FS 066 & 3.90 & 471 & 731 & 7.19 & Pitanga \\
\hline FS 129 & 3.97 & 504 & 793 & 7.8 & Pitanga \\
\hline FS 229 & 3.64 & 378 & 703 & 7.26 & Pitanga \\
\hline FS 236 & 3.64 & 382 & 681 & 7.03 & Pitanga \\
\hline FS 252 & 3.91 & 386 & 732 & 7.60 & Pitanga \\
\hline LH03 & 3.59 & 392 & 716 & 7.60 & Pitanga \\
\hline LH04 & 3.46 & 393 & 647 & 7.13 & Pitanga \\
\hline LH05 & 3.25 & 377 & 722 & 6.33 & Pitanga \\
\hline & & & & & \\
\hline
\end{tabular}




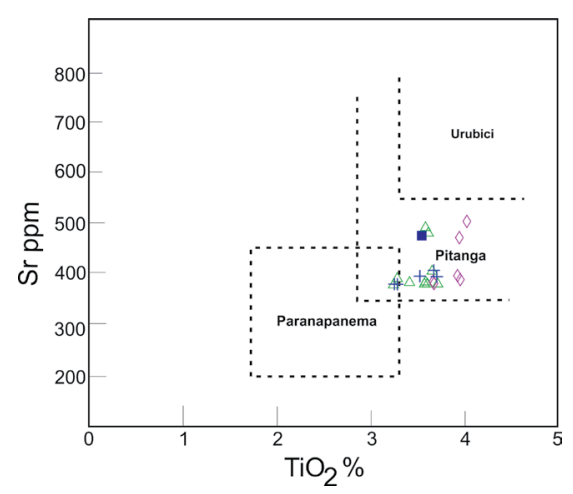

Empty squares: 18 samples from the Triângulo Mineiro and northeast of São Paulo (Rocha Junior et al., 2013); empty diamonds: Sacramento; full square: Uberaba; empty triangles: Uberlândia/Araguari and crosses: basalt flows related to pillow lavas).

Figure 18. $\mathrm{Sr} v \mathrm{~s}$. $\mathrm{TiO}_{2}$ diagram for high titanium magmatypes based in Peate et al. (1992) and Machado (2005).

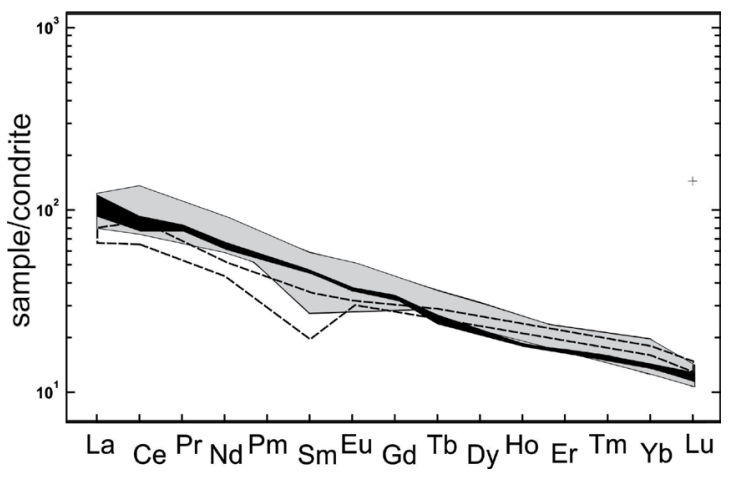

Figure 20. Chondrite-normalized rare Earth elements (REE) (black field) compared with Rocha Junior et al. (2013) data (gray field = Pitanga Magma; empty field = Paranapanema Magma).
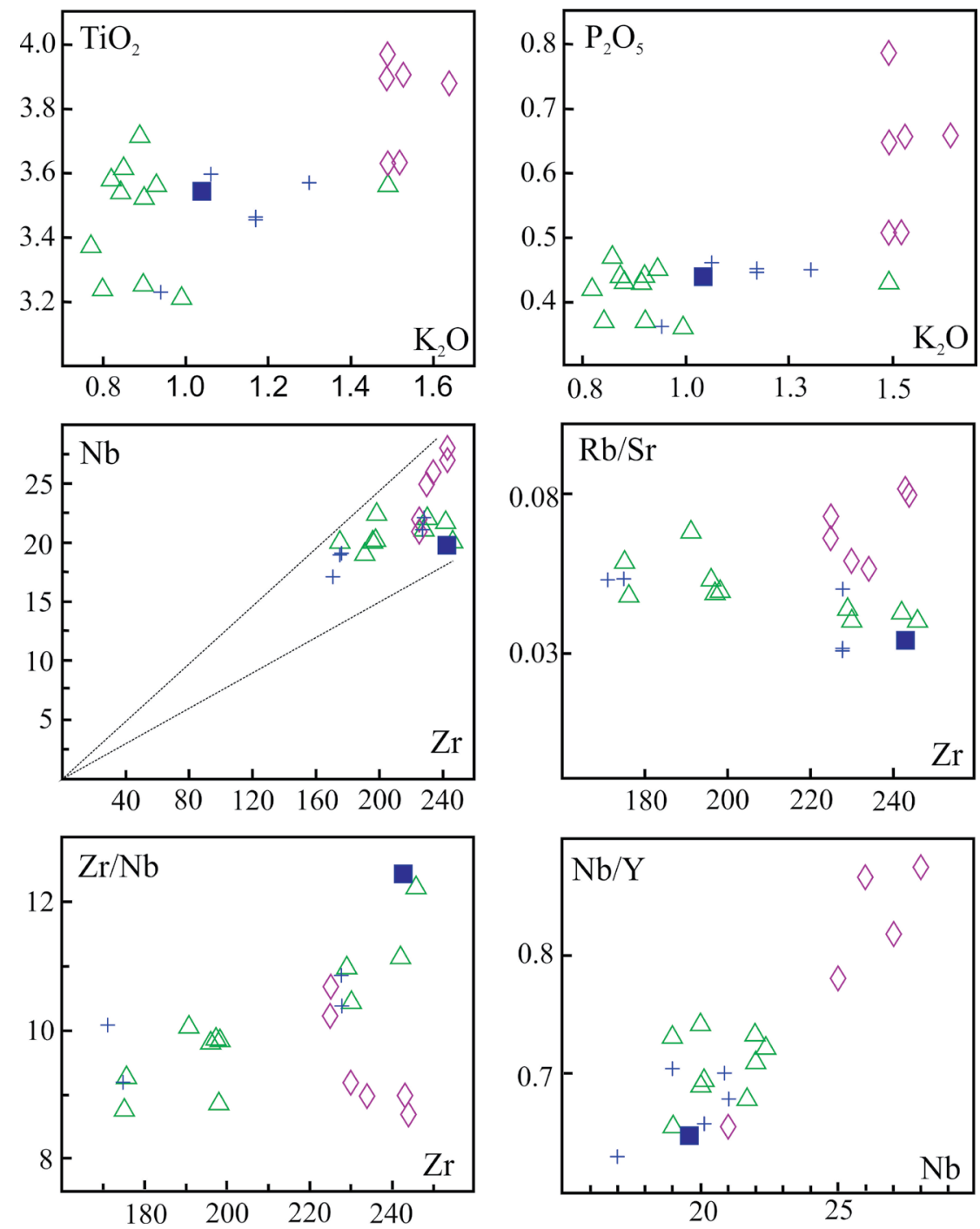

Figure 19. Diagrams variation in some major, minor and trace elements suggestive of different parental magmas. 
distinct morphology and chemistry. The rocks are basalts, with a tholeiitic signature, belong to the Serra Geral Group and are classified as Pitanga magma-type, of the high titanium group of basalts. The intertrapped sedimentary beds, aeolian or lacustrine in character, are important markers on prevailing environmental conditions, as well as quiescence periods in the volcanic activity.

Some zoned plagioclase and pyroxene crystals show inverted or alternating zoning from the core to the edge, which could indicate rapidly temperature variation. Still with respect to plagioclases, the ternary classification diagram $\mathrm{Ab}-\mathrm{An}-\mathrm{Or}$ shows overlaps between groundmass and phenocrysts compositions, suggesting simultaneous crystallization of them.

A pronounced chemical distinction can be seen between the rocks from the Uberlândia/Araguari region and those from the Sacramento region, which are more evolved than the first one. Attention is drawn to the independent behavior of rocks associated with pillow lavas, suggesting a possible alteration by water interaction. The origin of these magmas may be to the partial melting of a garnet peridotite mantle source, and the negative anomaly of $\mathrm{Nb}$ may be an inheritance of the subduction processes that affected the region during the Neoproterozoic.

The data presented reinforce the need for a more detailed lithostratigraphic control in order to advance the understanding of the processes that acted in the origin of this region of $\mathrm{PCMP}$.

\section{ACKNOWLEDGMENTS}

This work was supported by Fundação de Amparo à Pesquisa do Estado de Sáo Paulo (FAPESP) - Project 2012/06082-6. Professor Dr. Evandro F. de Lima gave us several hours of work on the UFG electronic microprobe, and Professor Dr. José Affonso Brod opened the doors of this laboratory generously, so we are grateful to both. The authors are really thankful to the reviewers' contribution for the paper, especially to Dr. Valdecir A. Janasi.

\section{REFERENCES}

Akimoto S.I., Katsura T. 1959. Magneto-chemical study of the generalized titanomagnetite in volcanic rocks. Journal of Geomagnetism and Geoelectricity, 10(3):69-90.

Araujo J.S. 1982. Estruturas Circulares de Água Vermelha. Dissertation, Instituto de Geociências da Universidade de São Paulo, São Paulo, São Paulo

Barcelos J.H. 1989. Influência do soerguimento do Alto Paranaíba na sedimentação pós basáltica na área do Triângulo Mineiro (MG), borda NNE da Bacia do Paraná. Geociências, 8:37-54.

Batezelli A. 2003. Análise da sedimentação cretácea no Triângulo Mineiro e sua correlação com áreas adjacentes. PhD Thesis, Universidade Estadual Paulista "Júlio de Mesquita Filho", Rio Claro, São Paulo.

Bellieni G., Comin-Chiaramonti P., Marques L.S., Martinez L.A., Melfi A.J., Nardy A.J.R., Papatrechas C., Piccirillo E.M., Roisenberg A., Stolfa D. 1986. Petrogenetic aspects of acid and basaltic lavas from the Paraná Plateau (Brazil): geological, mineralogical and petrochemical relationships. Journal of Petrology, 27:915-944

Bellieni G., Comin-Chiaramonti P., Marques L.S., Melfi A.J., Piccirillo E.M., Nardy A.J.R., Roisenberg A. 1984. High- and low-Ti flood basalts from the Paraná plateau (Brazil): petrology and geochemical aspects bearing on their mantle origin. Neues Jahrbuch für Mineralogie, 150:273-306

Deer W.A., Howie R.A., Zussman J. 2003. An Introduction to the RockForming Minerals. New York, Longman Scientific and Technical.

Ernesto M., Raposo M.I.B., Marques L.S., Renne P.R., Diogo L.A., De Min A. 1999. Paleomagnetism, geochemistry and 40Ar/39Ar dating of the North-eastern Paraná Magmatic Province: tectonic implications. Journal of Geodynamics, 28:321-340.
Ernesto M., Marques L.S., Piccirillo E.M., Molina E.C., Ussami N., Comin-Chiaramonti P., Bellieni G. 2002. Paraná Magmatic ProvinceTristan da Cunha plume system: fixed versus mobile plume, petrogenetic considerations and alternative heat sources. Journal of Volcanology and Geothermal Research, 118:15-36.

Ferreira C.M. 1985. Ocorrência de "pillow lava" em vulcanitos da Formação Serra Geral em Araguari, MG. In: 30 Simpósio de Geologia de Minas Gerais. Anais. Sociedade Brasileira de Geologia, Belo Horizonte, p. 235-237.

Fujimori S. 1990. Composição química de rochas e suas aplicações. Salvador, Centro Editorial e Didático da UFBA.

Ganguly S., Ray J., Koeberl C., Ntaflos T., Banerjee M. 2012. Mineral chemistry of lava flows from Linga area of the Eastern Deccan Volcanic Province, India. Journal of Earth System Science, 121(1):91-108.

Hasui Y. 1967. Geologia das formações cretáceas do Oeste de Minas Gerais. PhD Thesis, DEM Escola Politécnica, Universidade de São Paulo, São Paulo, São Paulo.

Hooper P.R. 2000. Chemical discrimination of Columbia River basalt flows. Geochemistry, Geophysics, Geosystems, 1(6):1-14. http://dx.doi. org/10.1029/2000GC000040

Irvine T.N., Baragar W.R.A. 1971. A guide to the chemical classification of the common volcanic rocks. Canadian Journal of Earth Sciences, 8(5):523-548.

Janasi V.A., de Freitas V.A., Heaman L.H. 2011. The onset of flood basalt volcanism, Northern Paraná Basin, Brazil: A precise $\mathrm{U}-\mathrm{Pb}$ baddeleyite/zircon age for a Chapecó-type dacite. Earth and Planetary Science Letters, 302(1):147-153. 
Jerram D.A., Stollhofen H. 2002. Lava-sediment interaction in desert settings; are all peperite-like textures the result of magmawater interaction? Journal of Volcanology and Geothermal Research, 114:231-249.

Katsura T., Kushiro I. 1961. Titanomaghemite in Igneous Rocks. The American Mineralogist, 46:134-145.

Le Bas M.J., Le Maitre R.W., Streckeisen A., Zannetin B.A. 1986. Chemical classification of volcanic rocks based on the total alkalisilica diagram. Journal of Petrology, 27(3):745-750.

Machado F.B. 2005. Geologia e Aspectos Petrológicos das Rochas Intrusivas e Efusivas Mesozoicas de parte da borda leste da Bacia do Paraná no Estado de São Paulo. Dissertation, Instituto de Geociências e Ciências Exatas, Universidade Estadual Paulista "Júlio de Mesquita Filho", Rio Claro, São Paulo.

Machado F.B. 2009. Petrologia e caracterização geoquímica das fontes mantélicas da região noroeste da Província Magmática do Paraná. PhD Thesis, Universidade Estadual Paulista "Júlio de Mesquita Filho", Rio Claro, São Paulo.

Mantovani M.S.M., Cordani U.G., Roisenberg A. 1985. Isotope geochemistry of acidic volcanics from the Parana basin and petrogenetic implications. Revista Brasileira de Geociências, 15:61-65.

Marques L.S., De Min A., Rocha-Júnior E., Babinski M., Bellieni G., Figueiredo A.M.G. 2017. Elemental and Sr-Nd-Pb isotope geochemistry of the Florianopolis dyke swarm (Paraná Magmatic Province): crustal contamination and mantle source constraints. Journal of Volcanology and Geothermal Research. http://dx.doi. org/10.1016/j.jvolgeores.2017.07.005

Marques L.S., Dupré B., Piccirillo E.M. 1999. Mantle source compositions of the Paraná Magmatic Province: evidence from trace element and $\mathrm{Sr}-\mathrm{N}-\mathrm{Pb}$ isotope geochemistry. Journal of Geodynamics, 28:439-459.

Marques L.S., Ernesto M. 2004. O magmatismo toleítico da Bacia do Paraná. In: Mantesso-Neto V., Bartorelli A., Carneiro C.D.R., Brito-Neves B.B. (Eds.) Geologia do Continente Sul-Americano: evolução da obra de Fernando Flávio Marques de Almeida. São Paulo, Beca. p. 245-263.

Marques L.S., Rocha-Júnior E.R.V., Babinski M., Carvas K.Z., Petronilho L.A., De Min A. 2016. Lead isotope constraints on the mantle sources involved in the genesis of Mesozoic high-Ti tholeiite dykes (Urubici type) from the São Francisco Craton (Southern Espinhaço, Brazil). Brazilian Journal of Geology, 46:105-122.

Moraes L.C., Seer H.J. 2017. Pillow lavas and fluvio-lacustrine deposits in the northeast of Paraná Continental Magmatic Province, Brazil, Journal of Volcanology and Geothermal Research. http:// dx.doi.org/10.1016/j.jvolgeores.2017.03.024

Morimoto N. 1988. Nomenclature of pyroxenes. Mineralogy and Petrology, 39(1):55-76.

Nardy A.J.R., Enzweiler J., Bahia F.O., Oliveira M.A.F., Peneiro M.A.V. 1997. Determinação de Elementos Maiores e Menores em Rochas Silicáticas por Espectrometria de Fluorescência de Raios-X: Resultados Preliminares. In: VI Congresso Brasileiro de Geoquímica. Anais... Sociedade Brasileira de Geologia, Salvador, p. 346-348.

Pacheco F.E.R.C., Caxito F.A., Moraes L.C., Marangoni Y.R., Santos P.R.S., Pedrosa-Soares A.C. 2017. Basaltic ring structures of the Serra Geral Formation at the southern Triângulo Mineiro, Água Vermelha region, Brazil. Journal of Volcanology and Geothermal Research. http://dx.doi.org/10.1016/j.jvolgeores.2017.06.019

Peate D.W. 1997. The Parana-Etendeka Province. In: Mahoney J.J., Coffin M.F. (Eds.) Large Igneous Provinces: Continental, Oceanic and Planetary Flood Volcanism. Washington, D.C., American Geophysical Union. p. 217-245.
Peate D.W., Hawkesworth C.J., Mantovani M.S. 1992. Chemical stratigraphy of the Paraná lavas (South America): classification of magma types and their spatial distribution. Bulletin of Volcanology, 55(1-2):119-139.

Petrelli M., Poli G., Perugini D., Peccerillo A. 2005. PetroGraph: a new software to visualize, model, and present geochemical data in igneous petrology. Geochemistry, Geophysics, Geosystems, 6(7). DOI: 10.1029/2005GC000932

Piccirillo E.M., Bellieni G., Cavazzini G., Comin-Chiaramonti P., Petrini R., Melfi A.J., Pinese J.P.P., Zantedeschi P., De Min A. 1990. Lower Cretaceous tholeiitic dyke swarms from the Ponta Grossa Arch (southeast Brazil): Petrology, Sr-Nd isotopes and genetic relationships with the Paraná flood volcanics. Chemical Geology, 89:19-48.

Piccirillo E.M., Melf A.J. 1988. The Mesozoic Flood Volcanism of the Paraná Basin: Petrogenetic and Geophysical Aspects. São Paulo, Universidade de São Paulo.

Pinto C.P., da Silva M.A. 2014. Mapa Geológico do Estado de Minas Gerais, 1.1.000.000. Belo Horizonte, CODEMIG-CPRM.

Pires E.F., Guerra-Sommer M., Scherer C.M.S., Santos A.R., Cardoso E. 2011. Early Cretaceous coniferous woods from a paleoerg (Paraná Basin, Brazil). Journal of South American Earth Sciences, 32:96-109.

Rao P.V.N., Swaroop P.C., Karimulla S. 2012. Mineral chemistry of Pangidi basalt flows from Andhra Pradesh. Journal of Earth System Science, 121(2):525-536.

Renne P.R., Ernesto M., Pacca I.G., Coe R.S., Glen J.M., Prévot M., Perrin M. 1992. The age of Paraná flood volcanism, rifting of Gondwanaland, and the Jurassic-Cretaceous boundary. Science, 5084:975-979.

Rocha-Júnior E.R.V., Marques L.S., Babinski M., Nardy A.J.R., Figueiredo A.M.G., Machado F.B. 2013. Sr-Nd-Pb isotopic constraints on the nature of the mantle sources involved in the genesis of the high-Ti tholeiites from northern Paraná Continental Flood Basalts (Brazil). Journal of South American Earth Sciences, 46:9-25.

Rocha-Júnior E.R.V., Puchtel I.S., Marques L.S., Walker R.J., Machado F.B., Nardy A.J.R., Babinski M., Figueiredo A.M.G. 2012. REE Os isotope and highly siderophile element systematics of the Paraná Continental Flood Basalts (Brazil). Earth and Planetary Science Letters, 337/338:164-173.

Rossetti L., Lima E.F., Waichel B.L., Hole M.J., Simões M.S., Claiton M.S., Scherer C.M.S. 2017. Lithostratigraphy and volcanology of the Serra Geral Group, Paraná-Etendeka Igneous Province in Southern Brazil: Towards a formal stratigraphic framework. Journal of Volcanology and Geothermal Research. http://dx.doi.org/10.1016/j. jvolgeores.2017.05.008

Sarmento C.C.T., Sommer C.A., Lima E.F. 2017. Mafic subvolcanic intrusions and their petrologic relation with the volcanism in the south hinge Torres Syncline, Parana-Etendeka Igneous Province, southern Brazil. Journal of South American Earth Sciences, 77:70-91.

Scherer C.M.S. 2002. Preservation of aeolian genetic units by lava flows in the Lower Cretaceous of the Paraná Basin, southern Brazil. Sedimentology, 49:97-116.

Seer H.J., Moraes L.C., Carneiro M.A. 2011. Geologia e litogeoquímica dos diques toleíticos ATi vinculados aos lineamentos magnéticos de direção NW do Arco do Alto Paranaíba em Abadia dos Dourados, MG. In: V Simpósio de Vulcanismo e Ambientes Associados. UFG, Goiás Velho.

Sun S.S., McDonough W.S. 1989. Chemical and isotopic systematics of oceanic basalts: implications for mantle composition and processes. Geological Society of London Special Publications, 42(1):313-345. 
Thiede D.S., Vasconcelos P.M. 2010. Paraná flood basalts: rapid extrusion hypothesis confirmed by new ${ }^{40} \mathrm{Ar} /{ }^{39} \mathrm{Ar}$ results. Geology, 38(8):747-750.

Turner S., Regelous M., Kelley S., Hawkesworth C.J., Mantovani M. 1994. Magmatism and continental break-up in the South Atlantic: high precision 40Ar-39Ar geochronology. Earth and Planetary Science Letters, 121:333-348.

Vernon R.H. 2004. A Practical Guide to Rock Microstructure. Cambridge, United Kingdom at the University Press.
Waichel B.L. 2006. Estruturação de Derrames e Interações LavaSedimento na Porção Central da Província Basáltica Continental do Paraná. PhD Thesis, Universidade Federal do Rio Grande do Sul, Porto Alegre, Rio Grande do Sul.

Wilson M. 2007. Igneous Petrogenesis: a global tectonic approach (10th ed.). The Netherlands, Springer.

Yavuz F. 2013. WinPyrox: a Windows program for pyroxene calculation classification and thermobarometry. American Mineralogist, 98:1338-1359. 